9. The Cichlid Fishes of Lake Victoria. By C.Tate Regan, M.A., F.R.S., F.Z.S., Keeper of Zoology in the British Museum (Natural History).

[Received January 6, 1922: Read February 21, 1922.]

$$
\text { (Plates I-IV.**; Text-figures 1-14.) }
$$

A revision of the Cichlidæ of Lake Victoria is a much more difficult task than that of revising the Cichlidæ of Nyassa, inasmuch as the types of all the described species from Nyassa are in the collection of the British Museum (Natural History), whereas a number of the types from Lake Victoria are in Paris, Berlin, and Genoa.

Dr. Pellegrin has kindly sent me notes on two or three species in the collection of the Paris Museum about which I had some doubts, and I am indebted to Mr. Boulenger for photographs of the types of Haplochromis nuchisquamulatus, H. obliquidens, $H$. longirostris, and $H$. sauvagei, which were sent to him by the late Professor Hilgendorf in 1898, and to Dr. Pappenheim for information about the first two of these species.

In Boulenger's 'Catalogue of African Freshwater Fishes' 47 species of Cichlidæ are described from Lake Victoria (including the Victoria Nile, Lakes Salisbury, Kioga, etc.). The number in the present revision is practically the same (50), but, as no less than 18 species are described below as new and some others formerly regarded as synonyms have been re-established, it will be evident that a considerable number of species recognized by Boulenger have been eliminated.

A summary of what is known of the Cichlidæ of the gुreat African lakes may now be given $\uparrow$.

From Lake Albert only three species have been recorded (Tilapia iilotica, Haplochromis wingatii, and H. multicolor), all of which occur also in the Bahr-el-Gebel.

Tilapia nilotica is found in Lakes Edward and Kivu; in addition, Lake Edward has a species of Tilapia (T. eduardiana) which is closely related to T.variabilis of Lake Victoria, 5 endemic species of Huplochromis, 4 apparently related to $H$. cinereus and the fifth to $H$. spekii, of Lake Victoria, and an endemic monotypic genus, Schubotzia, distinguished from Haplochromis by the dentition.

Kivu has five species of Haplochromis peculiar to the lake, of which two seem to be related to $H$. cinereus.

From Tanganyika 89 species belonging to 37 genera are known. Except Tilapia nilotica, all these are endemic and the majority of them belong to endemic genera. Nearly all the Tanganyika Cichlidæ belong to genera which may have evolved

* For explanation of the Plates see p. 191.

+ For Cichlidæ of Lakes Edward and Kivu, see Ann. \& Mag. Nat. Hist. (9) viii. 1921, p. 632 ; of Tanganyika, Ann. \& Mag. Nat. Hist. (9) v. 1920, p. 30 ; of Nyassa, P. Z.S. 1921, p. 675 . 
in the lake from two ancestral types, Limnotilapia and Haplochromis; but, although there are a number of genera which appear to be derived from Haplochromis, that genus itself is represented by two species only.

From Nyassa 84 Cichlidæ belonging to 14 genera* have been described, nearly all endemic. The most striking feature is the presence of 53 endemic species of Haplochromis, which appear to form a natural group and have evidently evolved in the lake from one or a few ancestral forms. Of the endemic genera four (with 12 species) are evidently derived from forms closely related to species of Haplochromis now living in the lake, and two more (Cynotilapia, Pseudotropheus) are related to Haplochromis. Of the others Hemitilapia and Otopharynx are near Tilapia, Chilotilapia is Otopharynx specialized, and Corematodus is mainly distinguished from the endemic Tilapia squamipinnis by its mouth and dentition. The indications are that the endemic Nyassa Cichlids have originated in the lake from about half-adozen ancestral forms.

In Lake Victoria there are 50 species of Cichlidæ, all peculiar to the lake except Tilapia zillii, a Nilotic species. The endemic species are a Tilapia, 44 Haplochromis, and 4 monotypic genera distinguished from Haplochromis by peculiarities of the dentition, or in one by an increased number of anal spines.

The species of Haplochromis exhibit almost as great a diversity as in Nyassa, yet there are certain features which enable one to say almost at a glance to which lake a species belongs. In most of the Nyassa Haplochromis the caudal fin is more or less distinctly emarginate, and is covered with small scales in the adult fish, whereas in most of the Victoria species it is rounded or truncate and is scaly only in the basai half. In the Nyassa Huplochromis a few distinctive types of coloration are prevalentfor example, 15 species have a dark band on each side from nape to caudal fin, and several others have four dark spots on each side; in most of the Victoria Haplochromis, when markings are present, they take the form of regular dark cross-bars with a dark band from head to caudal fin and another above the lateral line.

There can be little doubt that Haplochromis cinereus, a small species, with rather short decurved snout and moderately small and slightly oblique mouth, is a generalized type; species with these characters are widely distributed in African rivers. A number of species in Lake Victoria are closely related to H. cinereus, but differ in the dentition of the jaws or of the pharyngeals, in having thicker lips, more gill-rakers, a larger eye, etc.

Haplochromis serranus and its allies are somewhat larger

* In my paper I recognized 15, but I now find that Astatotilapia camnot be maintained as distinct from Haplochromis, several of the Lake Victoria species having enlarged teeth at the ends of the præmaxillaries more or less developed and not at all constant. 
species, with a larger mouth and more prominent lower jaw ; in some species of this group the mouth is oblique, and in some the outer teeth are strong and spaced. Finally, there are species with a strongly projecting lower jaw, in some of which the cleft of the mouth is nearly vertical.

One species, $H$. ishmaeli, is of peculiar interest; it is so like $H$. cinereus that the types (12 specimens) include 6 examples of the latter, but it differs in having much larger and more massive pharyngeals, with the teeth large and blunt, whereas in $H$. cinereus they are small and slender. I have described a similar pair of species (H.tetrastigma and $H$. placodon) from Nyassa. A remarkable group of three species includes Haplochromis sauvagei and the monotypic genera Macropleurodus and Hoplotilapia, which scarcely differ from each other except for the considerable differences in dentition, and seem to illustrate Cope's paradoxical view that a species may persist through several genera. It is especially interesting to note that the normal markings are those described above as characteristic of many Victoria species, but that in addition all three are known to possess a "bicolor" form, a sort of piebald, in which the dark pigment is concentrated into a number of blotches and irregular cross-bars which extend on to the vertical fins.

Another interesting example of the same species in different genera is provided by Haplochromis annectens and Platytceniodus degeni; here the former shows a slight departure from the normal Haplochromis dentition towards the Platytceniodus type.

The conclusion is that in Victoria most of the endemic Cichlidæ have evolved in the lake from a type very similar to Haplochromis cinereus, and that the primary evolution has been in the size and shape of the mouth, and the number, structure, and arrangement of the teeth, doubtless in adaptation to different kinds of food and different methods of feeding. The facts seem more in harmony with Gulick's theory of habitudinal segregation than with the modern idea of evolution by accidental mutations. The Cichlidæ of Tanganyika and Nyassa lead to the same conclusion.

In my paper on the Nyassa Cichlidæ I called attention to two striking examples of convergent evolution, Pseudotropheus and Aulonocara of Nyassa, respectively showing a great resemblance to Tropheus and Trematocura of Tanganyika. Lake Victoria provides some more examples: Haplochromis chilotes has the lips thick and produced into lobes as in Lobochilotes of Tanganyika; $H$. $i s h m a e t i$ has the pharyngeals massive and provided with large blunt teeth as in H.placodon of Nyassa. Further, Haplochromis obliquidens and Macropleurodus bear a resemblance to Nyassa genera in their dentition, the former to Hemitilapia, the latter to Chilotilapia.

If the degree of differentiation be taken as a guide, one may form the conclusion that the Cichlidæ have inhabited Tanganyika longer than Nyassa, and Nyassa longer than Victoria. 
From what has been said above as to the evolution and relationships of the Cichlidæe of Victoria, it will be evident that I do not regard the classification here proposed as entirely satisfactory. A number of divergent species are placed in Haplochromis and a few extreme types are regarded as generically distinct, although the close relationship of each to a species of Haplochromis is obvious. At present I am not in a position to improve this arrangement.

\section{Synopsis of the Genera.}

I. Scales cycloid

1. Tilapia.

II. Scales ctenoid.

A. Teeth in 2 or more series anteriorly; a single series on each side of upper jaw.

2. Haplochromis.

4 to 6 anal spines

3. Astatoreochromis.

B. Several series of teeth on each side of upper jaw.

1. Upper jaw with an outer series of enlarged teeth and several inner series of small teeth anteriorly, and 3 or 4 series of enlarged teeth laterally.

2. Teeth small, conical, in bands.

4. Macropleurodus.

Bands rather broad, narrower at the sides than in front ......

Bands very broad, upper broader at the sides than in front...

5. Hoplotilapia.

6. Platytaniodus.

\section{Tilapia A. Smith, 1840.}

Pharyngeal apophysis formed by parasphenoid only. Scales cycloid. An outer series of bicuspid teeth and several inner series of tricuspid teeth.

Africa and Syria.

1. Tilapia variabilis Bouleng., 1906.

Tilapia variabilis Bouleng. Cat. Afr. Fish. iii. p. 167, fig. 108.

Teeth in 4 to 8 series, 50 to 120 in outer series of upper jaw. 17 to 19 gill-rakers on lower part of anterior arch. Dorsal XVI-XVIII 10-13. Anal III (IV) 10-11. Pectoral longer than head.

Total length $320 \mathrm{~mm}$.

L. Victoria and Victoria Nile.

2. Tilapia zillii Gerv., 1848.

Tilapia zillii Bouleng. Cat. Afr. Fish. iii. p. 197, fig. 126.

Teeth in 3 to 6 series, 20 to 60 in outer series of upper jaw. 8 to 11 gill-rakers on lower part of anterior arch. Dorsal XIVXVI 10-13. Anal III 7-10. Pectoral usually not longer than head.

Total length $290 \mathrm{~mm}$.

Syria to the Niger and the Victoria Nile.

\section{Haplochromis Hilgendorf, 1888.}

Pharyngeal apophysis formed by parasphenoid in middle and basioccipital at sides. Scales ctenoid. Teeth in 2 or more series 
anteriorly, becoming a single series laterally, conical or compressed, unicuspid, or outer mostly bicuspid and inner tricuspid.

Africa and Syria.

All the species described below are peculiar to L. Victoria and the Victoria Nile. Haplochromis obliquidens, the type species, has a dentition unlike that of most of the species which have beer placed in this genus, but the discovery of a species in L. Kivu ( $H$. astatodon) some individuals of which have a typical Ctenochromis dentition, whilst others approximate to $\mathrm{H}$. obliquidens, makes it possible to regard this difference as only subgeneric and to still include species with conical or cuspidate teeth in Haplochromis.

\section{Synopsis of the L. Victoria Species.}

1. Teeth slender, cuspidate, in 5 to 8 series, the inner well developed and not separated by a distinct interspace from the outermost. (Neochromis Regan.)

Snout usually a little projecting beyond lower jaw, which is short and broad, about $\frac{1}{3}$ length of head

Jaws equal or lower slightly projecting, relatively slender, about $\frac{2}{5}$ length of head

1. nigricans.

2. muchisquamulatus.

II. Outermost series of teeth conical or bicuspid, enlarged, separated by an interspace from the smaller inner teeth. (Ctenochromis Pfeffer.)

A. Jaws equal anteriorly, or lower shorter than upper, or rarely slightly projecting.

1. Lips not produced into lobes.

a. Interorbital width not more than $\frac{1}{3}$ length of head.

a. Pharyngeal teeth slender.

* Lower jaw not shorter than upper; lips normal.

Caudal rounded; caudal peduncle as long as deep ; maxillary extending to below anterior part of eye ...................

Caudal subtruncate; caudal peduncle longer than deep; maxillary extending to below anterior edge of eye .......

Caudal truncate; 11 or 12 gill-rakers on lower part of anterior arch

Caudal truncate; 9 or 10 gill-rakers; eye 3 in head, twice præorbital depth

3. gestri.

4. nubilus.

5. melanopus.

Caudal truncate; 7 to 10 gill-rakers; eye more than 3 in head

6. macrops.

7. cinereus.

*** Lower jaw not shorter than upper; lips thick.

Teeth in 4 to 8 series, 30 to 4.6 in outer series of upper jaw... 8. sauvagei.

Teeth in 3 to 5 series, 20 to 24 in outer series of upper jaw... 9. crassilabris.

*** Lower jaw shorter than upper.............. 10. annectens.

3. Middle pharyngeal teeth stout, subconical ... 11. humilior.

$\gamma$. Pharyngeal teeth large, obtuse ............... 12. ishmaeli.

b. Interorbital width more than $\frac{1}{3}$ length of head. 13. obesus.

2. Lips thick, each produced into a lobe anteriorly ... 14. chilotes.

B. Lower jaw distinctly, but usually not strongly, projecting.

A. Outer teeth numerous, close together.

1. Maxillary not extending to below eye ....

15. taniatus.

2. Maxillary extending to below eye, or nearly.

a. Eye $\frac{1}{3}$ length of head or more (in specimens of 100 to $110 \mathrm{~mm}$.)......................... 16. martini.

b. Eye less than $\frac{1}{3}$ length of head, except in the very young.

a. Præmaxillary pedicels extending to between anterior edges of orbits ....

17. nigrescens.

$\beta$. Præmaxillary pedicels not reaching orbits. * Caudal peduncle $1 \frac{1}{3}$ to 2 as long as deep.

D. XIV-XV 9-10. 8 or 9 gill-rakers on lower part of anterior arch

18. flavipinnis.

Proc. Zool. Soc. -1922 , No. XI. 
D. XIV-XV 8-10. 10 to 12 gill-rakers on lower part of anterior arch .......................................

D. XV-XVII 9-10. 9 to 11 gill-rakers on lower part of anterior arch

19. microdon.

** Caudal peduncle once to $1 \frac{1}{3}$ as long as deep; 5 series of scales on cheek.

Depth of præorbital not greater than diameter of eye (in a

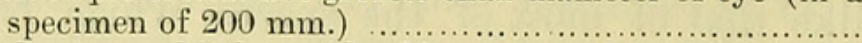

Depth of præorbital considerably greater than diameter of eye (in a specimen of $220 \mathrm{~mm}$.)

21. serranus.

** Caudal peduncle $1 \frac{1}{3}$ as long as deep ; 6 or 7 series of scales on cheek

23. squamulatus.

B. Outer teeth rather strong, set well apart.

Pectoral not reaching anal; caudal subtruncate; mouth little oblique

Pectoral reaching anal; caudal truncate ; mouth oblique ...

24. bayoni.

25. macrodon.

C. Lower jaw strongly projecting.

A. Pectoral reaching anal; caudal truncate; mouth moderately oblique; maxillary not extending to below eye.

Eye 5 in head (in a specimen of $170 \mathrm{~mm}$.)

Eye 4 in head (in a specimen of $180 \mathrm{~mm}$.)

26. prognathus.

B. Pectoral reaching anal, or nearly ; caudal rounded or subtruncate ; maxillary reaching vertical from anterior edge of eye.

1. Mouth moderately oblique; maxillary extending to below eye.

a. Præmaxillary pedicels ending above nostrils ... 28. dichrourus.

b. Præmaxillary pedicels ending well behind nostrils.

Maxillary extending to below anterior $\frac{1}{4}$ of eye ; caudal peduncle longer than deep

Maxillary barely reaching vertical from anterior edge of eye ; caudal peduncle as long as deep ...................

2. Mouth very oblique.

Maxillary reaching vertical from anterior edge of eye........

Maxillary not reaching vertical from anterior edge of eye ...

29. spekii.

30. serranoides.

31. acutirostris.

32. plagiostoma.

C. Pectoral not reaching anal; mouth not very oblique; lower jaw very prominent, with the anterior teeth exposed.

Outer teeth forming a close-set series; maxillary reaching vertical from anterior edge of eye

Outer teeth strong, spaced; maxillary not quite reaching. to below eye

Outer teeth strong, spaced; maxillary not nearly reaching to below eye

33. macrognathus.

34. dentex.

35. mento.

D. Pectoral not reaching anal; mouth very oblique.

1. 8-10 scales from origin of dorsal to lateral line ..

2. 5 to 7 scales from origin of dorsal to lateral line.

a. Depth of body $2 \frac{3}{5}$ in the length

b. Depth of body 3 to $4 \frac{1}{4}$ in length,

a. Caudal peduncle $1 \frac{1}{3}$ to $1 \frac{1}{2}$ as long as deep.

Lower jaw projecting upwards above end of snout .............

Lower jaw not projecting above end of snout; maxillary not quite reaching vertical from anterior edge of eye

Lower jaw not projecting above end of snout; maxillary ending midway between nostril and eye... ...............

$\beta$. Caudal peduncle $1 \frac{3}{4}$ to $2 \frac{1}{4}$ as long as deep.

Snout $1 \frac{2}{3}$ to twice diameter of eye (in specimens of 100 to $160 \mathrm{~mm}$.)

Snout $1 \frac{1}{3}$ to $1 \frac{2}{3}$ diameter of eye (in specimens of 115 to $150 \mathrm{~mm}$.)

36. cavifrons.

37. orthostoma.

38. xenostoma.

39. pellegrini.

40. argenteus.

41. longirostris.

42. gracilicauda.

III. Outer teeth few and large, with long anterior cusp and indistinct posterior cusp (Bayonia Bouleng.) ….................... 43. xenodon.

IV. Teeth slender, distally expanded and compressed, outer obliquely truncated (Haplochromis Hilgend.)

44. obliquidens. 
1. Haplochromis nigricans Bouleng., 1906.

Tilapia nigricans (part.) Bouleng. Cat. Afr. Fish. iii. p. 240, fig. 160.

T'lapia simotes Bouleng. t.c. p. 242, fig. 161.

Depth of body $2 \frac{1}{2}$ to 3 in length, length of head 3 to $3 \frac{1}{3}$. Snout decurved, about as long as diameter of eye, which is $3 \frac{1}{4}$ to $3 \frac{2}{3}$ in length of head, greater than præorbital depth, equal to interorbital width. Jaws equal or lower jaw a little the shorter, short and broad, about $\frac{1}{3}$ length of head; maxillary reaching vertical from anterior edge of eye or a little beyond; teeth slender, cuspidate, in 6 to 8 series, outer but little enlarged and not separated by a distinct interspace from inner; 40 to 70 in outer series of upper jaw. 3 or 4 series of scales on cheek. 7 to 10 gill-rakers on lower part of anterior arch. Pharyngeal teeth small. 31 to 33 scales in a longitudinal series, 5 or 7 from origin of dorsal to lateral line. Dorsal XV-XVI 9-10 ; last spine $\frac{1}{2}$ length of head. Anal III 8-9; third spine nearly as long as last dorsal. Pectoral a little shoiter than head, not rexching anal. Caudal truncate or subtruncate. Caudal peduncle as long as or a little longer than deep. Brownish or greyish, with traces of blackish cross-bars; males with 2 to 4 ocelli on anal.

Nine specimens, including types of $T$. nigricans and $T$. simotes, 70 to $145 \mathrm{~mm}$. in total length, and a skeleton.

Boulenger's figures show 'T. nigricuns as having quite a different physiognomy from $T$. simotes, but this is because the head is directed upwards in the former.

\section{Haplochromis nuchisquamulatus Hilgendorf, 1888.}

Chromis nuchisquamulatus Hilgend. Sitzb. Ges. naturf. Fr. Berlin, 1888, p. 76.

Ctenochromis nuchisquamulatus Pfeffer, Thierw. O.-Afr. Fische, p. 14 (1896).

Tilapia nigricans (part.) Bouleng. Cat. Afr. Fish. iii. p. 240.

Haplochromis nuchisquamulatus (part.) Bouleng. t. c. p. 290.

Depth of body $2 \frac{2}{3}$ in length, length of head 3 to $3 \frac{1}{3}$. Snout with straight profile, about as long as diameter of eye, which is $3 \frac{1}{3}$ to $3 \frac{2}{3}$ in length of head, greater than praorbital depth, equal to or greater than depth of cheek ; interorbital width $3 \frac{1}{3}$ to $3 \frac{1}{2}$ in length of head. Jaws equal or lower slightly projecting; rami of lower jaw longer and more slender than in $H$. nigricans, about $\frac{2}{5}$ length of hear. Teeth as in the preceding species, in 5 to 8 series, 50 to 80 in outer series of upper jaw. 2 or 3 series of seales on cheek. 9 to 11 gill-rakers on lower part of anterior arch. Pharyngeal teeth small. 31 to 33 scales in a longitudinal series, 5 or 6 from origin of dorsal to lateral line. Dorsal XVXVI 9-10 ; last spine $\frac{1}{2}$ length of head. Anal III 9-10 ; third spine $\frac{2}{5}$ to $\frac{1}{2}$ head. Pectoral as long as or a little shorter than 
head, nearly or quite reaching anal. Caudal truncate. Caudal peduncle $1 \frac{1}{4}$ to $1 \frac{1}{3}$ as long as deep. Silvery or greyish, with or without 8 dark cross-bars; an opercular spot; sometimes a bar below eye.

Lake Victoria.

Two specimens, 100 and $145 \mathrm{~mm}$. long, from Kakindu (Bayon) and Buddu Coast (Simon), and two skeletons.

Very near H. nigricans; the difference in the structure of the lower jaw is well seen on comparing the skeletons.

3. Haplochromis gestri Bouleng., 1911.

Haplochromis desfontainesii (part.) Bouleng. Cat. Afr. Fish. iii. p. 302.

Paratilapica gestri (part.) Bouleng. t. c. p. 318, fig. 211.

Depth of body $2 \frac{1}{3}$ to 3 in length, length of head $2 \frac{2}{3}$ to 3 . Snout with straight or convex profile, from as long as to $1 \frac{1}{2}$ diameter of eye, which is $3 \frac{1}{2}$ to $4 \frac{1}{3}$ in length of head, greater than præorbital depth, in adults less than depth of cheek; interorbital with $3 \frac{1}{2}$ to $4 \frac{1}{2}$ in length of head. Jaws equal anteriorly or lower slightly projecting; præmaxillary pedicels not quite reaching to between orbits; maxillary extending to below anterior $\frac{1}{4}$ or $\frac{1}{3}$ of eye; teeth in 2 to 4 series, conical in adult, 34 to 60 in outer series of upper jaw. 3 to 5 series of seales on cheek. 8 gill-rakers on lower part of anterior arch. Pharyngeal teeth small. 30 to 33 scales in a longitudinal series, 5 or 6 from origin of dorsal to lateral line. Lorsal XV-XVI 8-10; last spine $\frac{2}{5}$ to $\frac{1}{2}$ length of head. Anal III 8-10; third spine $\frac{1}{3}$ or $\frac{2}{5}$ head. Pectoral $\frac{2}{3}$ to $\frac{4}{5}$ head, reaching vent. Caudal rounded. Caudal peduncle as long as deep. Often a dark band from opercular spot to base of caudal, sometimes a second above lateral line; a bar below eye usually present; soft dorsal and caudal with or without spots; males with blackish pelvic fins and ocelli on the anal.

Several specimens, 70 to $160 \mathrm{~mm}$. long.

\section{Haplochromis nubilus Bouleng., 1906.}

? Paratilapia victoriana Pellegrin, Bull. Soc. Zool. France, 1903, p. 185, and Mem. xvii. 1905, p. 182, pl. xvii. fig. 3.

Tilapia nubila Bouleng. Cat. Afr. Fish. iii. p. 235, fig. 155.

Haplochromis nuchisquamulatus (part.) Bouleng. t. c. p. 290, fig. 197.

Haplochromis desfontainesii (part.) Bouleng. t. c. p. 302.

Depth of body $2 \frac{1}{2}$ to 3 in length, length of head $2 \frac{2}{3}$ to 3 . Snout as long as or a little longer than diameter of eye, which is 3 to 4 in length of head, greater than præorbital depth, in adult equal to depth of cheek; interorbital width $3 \frac{1}{3}$ to 4 in length of head. Jaws equal anteriorly, or lower feebly projecting; maxillary extending to below anterior edge of eye ; teeth cuspidate, or some conical, in 2 to 5 series, 40 to 60 in outer series of upper jaw. 3 or 4 series of scales on cheek. 8 to 10 gill-rakers on lower part 
of anterior arch. Pharyngeal teeth small. 30 to 32 scales in a longitudinal series, 4 to 6 from origin of dorsal to lateral line. Dorsal XV-XVI 8-10; last spine $\frac{2}{3}$ to $\frac{1}{2}$ length of head. Anal III 8-10; third spine as long as or a little shorter than last dorsal. Pectoral $\frac{3}{4}$ to as long as head, reaching vent or anal fin. Caudal subtruncate. Caudal peduncle longer than deep. Olivaceous or greyish to blackish, uniform or with dark cross-bars; often an opercular spot and a dark bar below eye; anal fin with ocelli in males.

Numerous examples up to $125 \mathrm{~mm}$. in total length.

Paratilapia victoriana Pellegrin appears to be very closely related to, if not identical with, $H$. nutilus, but if the figure be accurate the pectoral fin is longer than in any examples of $H$. nubilus that I have examined, reaching the middle of the anal.

5. Haplochronis melanopus, sp. n. (Text-fig. 1.)

Tilapia lacrimosa (part.) Bouleng. Cat. Afr. Fish. iii. p. 234.

Haplochromis stanleyi (part.) Bouleng. t. c. p. 295.

Depth of body $2 \frac{2}{3}$ to 3 in length, length of head 3 to $3 \frac{1}{3}$. Snout decurved, as long as or a little shorter than diameter of eye, which

Text-figure 1.

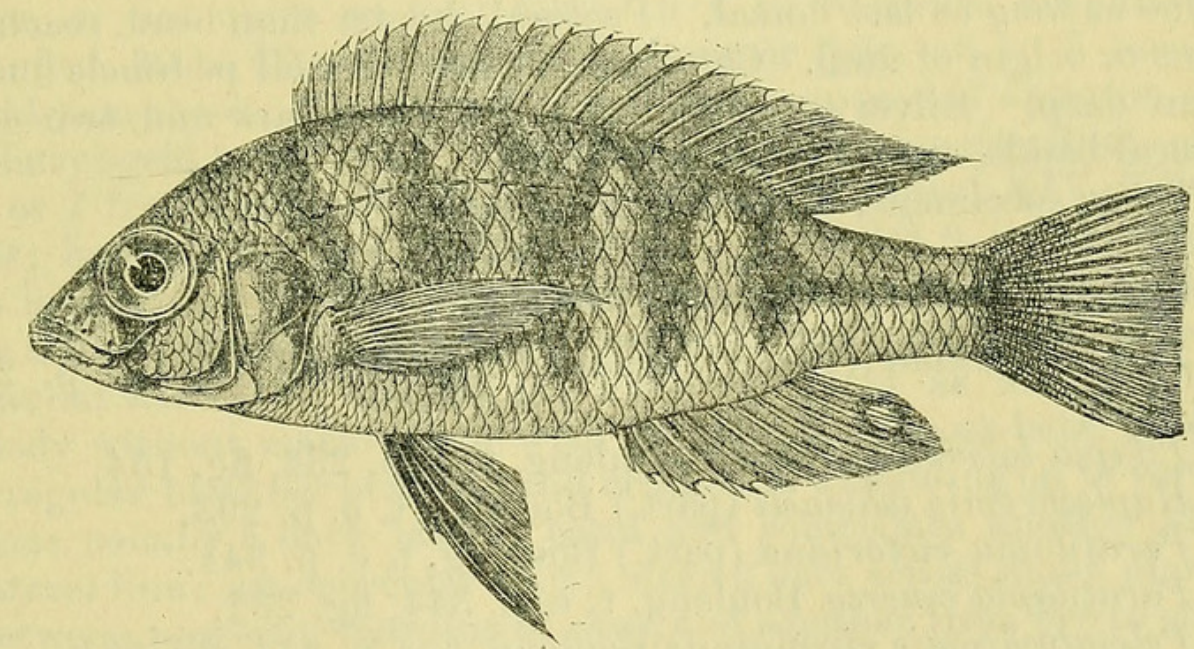

Haplochromis melanopus, sp. 11.

is 3 to $3 \frac{1}{2}$ in length of head, greater than depth of cheek, not twice præorbital depth; interorbital width $3 \frac{1}{2}$ to $3 \frac{3}{4}$ in length of hear. Jaws equal anteriorly: maxillary extending to below anterior edge of eys; teeth cuspidate or some conical, in 2 to 4 series, 50 to 65 in outer series of upper jaw. 3 to 4 series of scales on cheek. 11 or 12 gill-rakers on lower part of anterior arch. Pharyngeal teeth small. 33 scales in a longitudinal series, 6 or 7 from origin of dorsal to lateral line. Dorsal XVI 8-9; last spine $\frac{2}{5}$ to $\frac{1}{2}$ length of head. Anal III 8-9; third spine $\frac{1}{3}$ to nearly $\frac{1}{2}$ length of head. Pectoral as long as or a little shorter than head, 
reaching vent or origin of anal. Caudal peduncle $1 \frac{1}{4}$ to $1 \frac{1}{2}$ as long as deep. About 6 more or less distinct dark cross-bars; sometimes an interrupted lateral band; an opercular spot; a dark bar below eye; soft dorsal and caudal spotted; pelvics blackish ; 1 to 3 ocelli on anal fin.

Seven specimens, 80 to $100 \mathrm{~mm}$. long, from Entebbe and Bunjako.

6. Haplochromis macrops Bouleng., 1911.

?.Astatotilapia jeannelli Pellegrin, Bull. Soc. Zool. France, xxxvii. 1913, p. 313.

Tilapia macrops Bouleng. Cat. Afr. Fish. iii. p. 238, fig. 157.

Haplochromis stanleyi (part.) Bouleng. t. c. p. 295.

Depth of body $2 \frac{3}{4}$ to 3 in length, length of head 3. Snout shorter than diameter of eye, which is 3 in length of head, slightly greater than interorbital width, twice præorbital depth. Jaws equal anteriorly; maxillary extending to vertical from anterior edge of eye; teeth in 4 or 5 series in upper jaw, 3 or 4 in lower, outer bicuspid or some conical, 50 to 60 in outer series of upper jaw. 3 series of scales on cheek. 9 or 10 gill-rakers on lower part of anterior arch. Pharyngeal teeth small. 32 scales in a longitudinal series, 5 or 6 from origin of dorsal to lateral line. Dorsal XV 9; last spine $\frac{2}{5}$ length of head. Anal III 10 ; third spine as long as last dorsal. Pectoral shorter than head, reaching vent or origin of anal. Caudal truncate. Caudal peduncle longer than deep. Silvery, with or without cross-bars and two dark lateral bands, or uniformly blackish.

Three specimens, 85 to $105 \mathrm{~mm}$. long.

\section{Haplochromis cinereus Bouleng., 1906.}

Tilapia pallida (part.) Bouleng. Cat. Afr. Fish. iii. p. 231, fig. 152.

Tilapia lacrimssa (part.) Bouleng. t. c. p. 234, fig. 154.

Haplochromis ishmaeli (part.) Bouleng. t. c. p. 293.

Paratilupia victoriana (part.) Bouleng. t. c. p. 341.

Paratilapia cinerea Bouleng. t. c. p. 344, fig. 232.

Pelmatochromis riponianus Bouleng. t. c. p. 411, fig. 281.

Pelmatochromis obesus (part.) Bouleng. t. c. p. 414.

Depth of body $2 \frac{1}{2}$ to $3 \frac{1}{3}$ in length, length of head $2 \frac{2}{3}$ to $3 \frac{1}{4}$. Snout decurved, nearly as long as or longer than diameter of eye, which is $3 \frac{1}{3}$ to $4 \frac{1}{2}$ in length of head and greater than depth of præorbital; interorbital width $3 \frac{1}{2}$ to 4 in length of head. Mouth slightly oblique; jaws equal anteriorly; maxillary extending to below anterior margin of eye, or nearly; teeth in 3 to 6 series in upper jaw, in 2 to 5 in lower, 36 to 70 in outer series of upper jaw. Pharyngeal teeth small. 7 to 10 gill-rakers on lower part of anterior arch. 30 to 34 scales in a longitudinal series, 6 or 7 from origin of dorsal to lateral line. Dorsal XIV-XVI 8-10; last spine $\frac{1}{3}$ to $\frac{1}{2}$ length of head. Anal III 8-10; third spine as 
long as or shorter than last dorsal. Pectoral as long as head, or a little shorter, extending to origin or anterior part of anal. Caudal truncate. Caudal peduncle $1 \frac{1}{4}$ to $1 \frac{3}{4}$ as long as deep. Silvery or greyish, with or without dark cross-bars and a continnous or interrupted lateral hand; often bars across the snout and a vertical one below the eye; males with pelvic fins dusky and ocellar spots on anal fin.

Lake Victoria.

Numerous examples up to $140 \mathrm{~mm}$. in total length.

\section{Haplochromis sauvagei Pfeffer, 1896.}

Ctenochromis sauvagei Pfeffer, Thierw. O.-Afr. Fische, p. 14.

Paratilapia granti (Bouleng., 1906) Bouleng. Cat. Afr. Fish. iii. p. 342, fig. 231.

Paratilapia crassilabris (part.) Bouleng. t. c. p. 345.

Paratilapia bicolor (part.) Bouleng. t. c. p. 346.

Paratilapia retrodens (part.) Bouleng. t. c. p. 347, fig. 235.

Depth of body $2 \frac{2}{3}$ to $3 \frac{1}{4}$ in length, length of head $2 \frac{3}{4}$ to $3 \frac{1}{3}$. Snout as long as or longer than diameter of eye, which is $3 \frac{1}{2}$ to $4 \frac{1}{2}$ in length of head, greater than præorbital depth, from a little greater to a little less than depth of cheek; interorbital width $3 \frac{1}{3}$ to 4 in length of head. Mouth as broad as long; lips thick; jaws equal anteriorly; maxillary extending to below anterior edge of eye, or not quite so far; teeth in 4 to 8 series, cuspidate or conical, 30 to 46 in outer series of upper jaw. 3 to 5 series of scales on cheek. 7 to 9 gill-rakers on lower part of anterior arch. Pharyngeal teeth small. 32 to 34 scales in a longitudinal series, 6 or 7 from origin of dorsal to lateral line. Dorsal XIV-XVI 910 ; last spine $\frac{1}{3}$ to $\frac{1}{2}$ length of head. Anal III 8-9; third spine as long as or a little shorter than last dorsal. Pectoral as long as or a little shorter than head, reaching vent or origin of anal. Caudal truncate. Caudal peduncle $1 \frac{1}{4}$ to $1 \frac{1}{2}$ as long as deep. Body without markings or with regular dark cross-bars, or with irregular blackish blotches and cross-bars extending on to vertical fins; usually a dark lateral band and sometimes another above lateral line; an opercular spot; often 2 bars across snout, another between posterior margins of eyes, and another from eye to end of maxillary; soft dorsal and caudal sometimes spotted; males with 1 to 3 ocelli on anal fin.

Numerous specimens 80 to $150 \mathrm{~mm}$. in total length.

\section{Haplochromis crassilabris Bouleng., 1906.}

Paratilapia crassilabris (part.) Bouleng. Cat. Afr. Fish. iii. p. 345 , fig. 233 .

Paratilapic retrodens (part.) Bouleng. t. c. p. 347.

Depth of body $2 \frac{2}{3}$ to 3 in length, length of head 3 . Snout from as long as to $1 \frac{1}{2}$ diameter of eye, which is $3 \frac{1}{2}$ to $4 \frac{1}{2}$ in length of head, greater than præorbital depth, about equal to depth of cheek; interorbital width $3 \frac{1}{2}$ in length of head. Mouth broader 
than long; lips thick; jaws equal anteriorly; maxillary not extending to below eye ; teeth in 3 to 5 series, outer strong, conical in adult, 20 to 24 in outer series of upper jaw. 3 series of scales on cheek. 7 to 9 gill-rakers on lower part of anterior arch. Pharyngeal teeth small. 31 to 33 scales in a longitudinal series; 6 or 7 from origin of dorsal to lateral line. Dorsal XV-XVI 810 ; last spine from a little less to a little more than $\frac{2}{5}$ length of head. Anal III 8-9; third spine as long as or a little shorter than last dorsal. Pectoral a little shorter than head, reaching: origin of anal. Caudal truncate or subtruncate. Caudal peduncle $1 \frac{1}{5}$ to $1 \frac{2}{5}$ as long as deep. An opercular spot; traces of dark cross-bars and a dark lateral band.

Four specimens, 100 to $150 \mathrm{~mm}$. long, from Entebbe; several smaller examples are not included in the description.

10. Haplochromis annectens, sp. n. (Text-fig. 2.)

Haplochromis ishmaeli (part.) Bouleng. Cat. Afr. Fish. iii. p. 293.

Depth of body $2 \frac{3}{4}$ in length, length of head 3. Snout decurved, a little longer than diameter of eye, which is 4 in length of head,

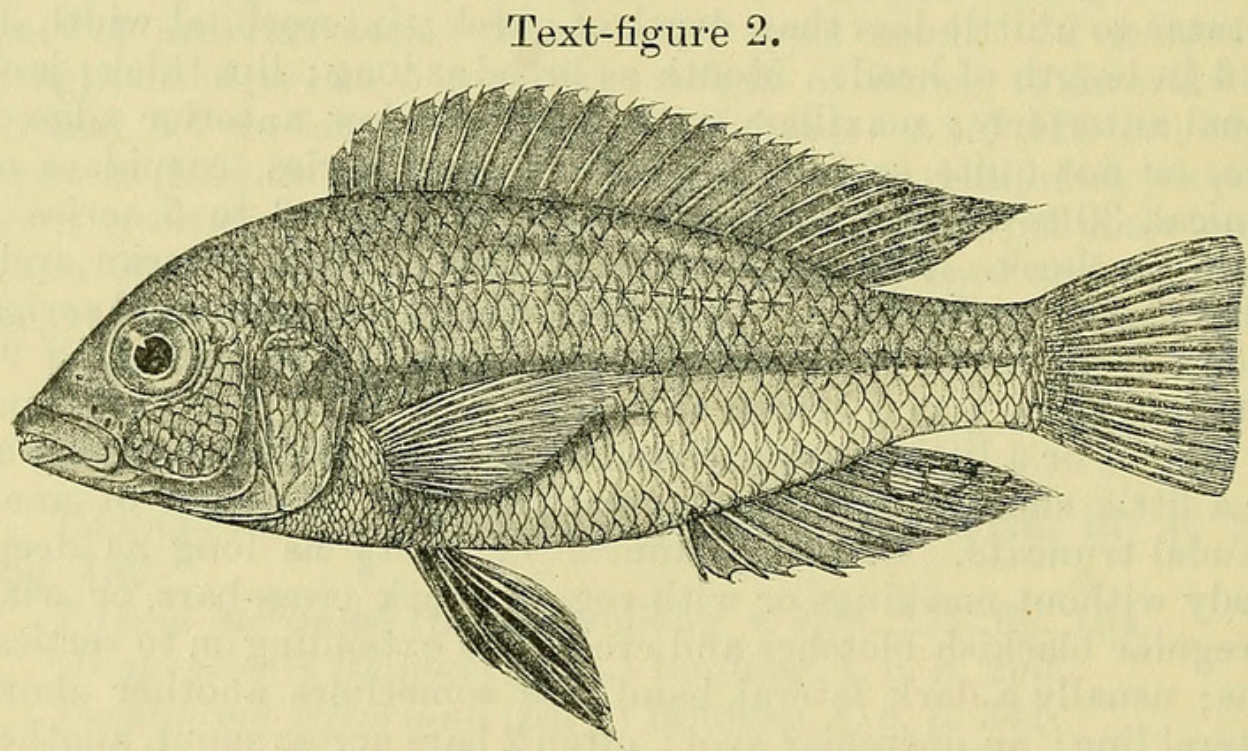

Haplochromis annectens, sp. $\mathrm{n}$.

nearly twice præorbital depth, equal to depth of cheek; interorbital width $3 \frac{1}{2}$ in length of head. Lips thick; lower jaw shorter than upper; maxillary extending to below anterior edge of eye. Teeth conical, in 4 or 5 series ; outermost series enlarged, 36 in upper jaw ; inner series of upper jaw forming a band which narrows slightly at the sides and then slightly increases in width at each end. 4 series of scales on cheek. 8 gill-rakers on lower part of anterior arch. Pharyngeal teeth small. 32 scales in a longitudinal series, 7 from origin of dorsal to lateral line. Dorsal XVI 9 ; last spine $\frac{2}{5}$ length of head. Anal III 9 ; third spine $\frac{2}{5}$ head. Pectoral as long as head, reaching anal. Caudal truncate. 
Caudal peduncle longer than deep. A dark lateral band from opercular spot to base of caudal; a dark bar below anterior part of eye; pelvies blackish; 3 ocelli on anal.

A single specimen, $130 \mathrm{~mm}$. in total length, from Buddu Coast.

11. Haplochromis humilior Bouleng., 1909.

Tilapia humilior Bouleng. Cat. Afr. Fish. iii. p. 230, fig. 151.

Tilapia bayoni Bouleng. t. c. p. 240, fig. 159 .

Depth of body 3 to $3 \frac{1}{3}$ in length, length of head 3 . Snout decurved, as long as or a little shorter than diameter of eye, which is $3 \frac{1}{3}$ in length of head, nearly twice depth of præorbital, greater than depth of cheek; interorbital width $4 \frac{1}{2}$ in length of head. Jaws equal anteriorly; maxillary extending to below anterior margin of eye or a little beyond ; teeth cuspidate, in 4 to 6 series, 54 to 70 in outer series of upper jaw. 3 to 4 series of scales on cheek. 7 or 8 gill-rakers on lower part of anterior arch. Middle pharyngeal teeth rather stout, subconical. 33 or 34 scales in a longitudinal series, 7 from origin of dorsal to lateral line; pectoral seales very small. Dorsal XV-XVI 9-10; last spine $\frac{1}{2}$ or nearly $\frac{1}{2}$ length of head. Anal III 8-10; third spine $\frac{1}{3}$ to a little more than $\frac{2}{5}$ length of head. Pectoral shorter than head, not reaching anal. Caudal subtruncate. Caudal peduncle $1 \frac{1}{4}$ to $1 \frac{1}{2}$ as long as deep. Silvery, brassy, or coppery; back darker; a dark bar below eye; males with 2 or 3 ocelli on anal.

Three specimens, 100 to $130 \mathrm{~mm}$. long, one of the types of the species and two types of $T$. bayoni. The second specimen of 'T. humilior is in very poor condition and is not included in the description.

12. Haplochromis ishmaeli Bouleng., 1906.

Tilapia pallida (part.) Bouleng. Cat. Afr. Fish. iii. p. 231.

Haplochromis ishmaeli (part.) Bouleng. t. c. p. 293, fig. 199.

Paratilapia victoriana (part.) Bouleng. t. c. p. 341, fig. 230.

Depth of body $2 \frac{1}{2}$ to 3 in length, length of head $2 \frac{2}{3}$ to 3 . Snout decurved, about as long as diameter of eye, which is $3 \frac{1}{4}$ to $3 \frac{3}{4}$ in length of head, considerably greater than præorbital depth, equal to or greater than depth of cheek; interorbital width $3 \frac{1}{3}$ to 4 in head. Jaws equal anteriorly or lower very slightly projecting; maxillary extending to below anterior edge or anterior $\frac{1}{4}$ of eye ; teeth cuspirlate or conical, in 3 or 4 series, 34 to 60 in outer series of upper jaw. 3 or 4 series of scales on cheek. 8 or 9 gill-rakers on lower part of anterior arch. Lower pharyngeal broad and massive, with strong blunt teeth. 31 to 33 scales in a longitudinal series, 6 to 8 from origin of dorsal to lateral line. Dorsal XV-XVI 9-10; last spine $\frac{1}{3}$ to $\frac{2}{5}$ length of head. Anal III 8-9; third spine as long as or a little shorter than last dorsal. Pectoral as long as head, extending to above anterior part of anal. Caudal truncate. Caudal peduncle $1 \frac{1}{3}$ to $1 \frac{1}{2}$ as long: 
as deep. Silvery, with or without dark cross-bars; sometimes an interrupted lateral band; an opercular spot; usually a bar below eye; soft dorsal and caudal sometimes spotted; males with ocelli on anal fin.

Several specimens, 90 to $135 \mathrm{~mm}$. in total length.

The remarkable pharyngeal dentition might well be held to justify the genus Labrochromis (Regan, 1920), were it not that in all other characters the species is nearly identical with $H$.cinereus.

\section{Haplochromis obesus Bouleng., 1906.}

Pelmatochromis obesus (part.) Bouleng. Cat. Afr. Fish. iii. p. 414, fig. 283.

Depth of body 2 in length, length of head 3. Snout longer than diameter of eye, which is 4 in length of head, greater than depth of præorbital, less than depth of cheek; interorbital width $2 \frac{2}{3}$ in length of head. Mouth wide, oblique; lower jaw not projecting; maxillary exposed, extending to below eye; teeth rather stout, conical, biserial, about 50 in outer series of upper jaw. 4 series of scales on cheek. 10 gill-rakers on lower part of anterior arch. Pharyngeal teeth small. 32 scales in a longitudinal series, 7 from origin of dorsal to lateral line. Dorsal XV 9 ; last spine $\frac{2}{5}$ length of head. Anal III 8 ; third spine $\frac{1}{3}$ head. Pectoral as long as head, reaching anal. Caudal truncate. Caudal penduncle as long as deep. Traces of dark cross-bars; an opercular spot and a bar beiow eye ; soft dorsal spotted ; anal fin with 3 ocelli ( $\left.\sigma^{*}\right)$.

One of the types, $150 \mathrm{~mm}$. long.

An isolated species, for which I proposed the generic name Lipochromis ('Annals,' 1920).

\section{Haplochromis chilotes Bouleng., 1911.}

Paratilapia chilotes Bouleng. Cat. Afr. Fish. iii. p. 338, fig. 228.

Depth of body 3 in length, length of head $2 \frac{2}{3}$. Diameter of eye 4 in length of head. Jaws equal anteriorly; lips very thick, each produced anteriorly into a lobe; maxillary not extending to below eye ; teeth small, conical. 3 series of scales on cheek. 8 or 9 gill-rakers on lower part of anterior arch. 31 or 32 scales in a longitudinal series. Dorsal XVI-XVII 9. Anal III 8-9. Pectoral $\frac{3}{4}$ head. Caudal truncate. Dark cross-bars and a lateral band.

Total length $98 \mathrm{~mm}$.

\section{Haplochromis teniatus, sp. n. (Text-fig. 3.)}

Paratilapia prognatha (part.) Bouleng. Cat. Afr. Fish. iii. p. 333 .

Depth of body $3 \frac{1}{4}$ in length, length of head $2 \frac{2}{3}$. Head $2 \frac{3}{3}$ to $2 \frac{3}{4}$ as long as broad; rpper profile slightly concave. Snout $1 \frac{1}{2}$ to $1 \frac{3}{4}$ diameter of eye, which is 4 to $4 \frac{1}{2}$ in length of head, greater 
than præorbital depth, equal to or greater than depth of cheek; interorbital width 5 in length of head. Maxillary not extending to below eye; lower jaw moderately projecting; chin obtuse; teeth in 3 series in upper jaw, 2 or 3 in lower, some of the inner tricuspid, outer series conical, 40 in upper jaw, anterior moderately strong. 3 series of scales on cheek. 8 or 9 gill-rakers on lower part of anterior arch. Dorsal XV-XVI 9; last spine

Text-figure 3.

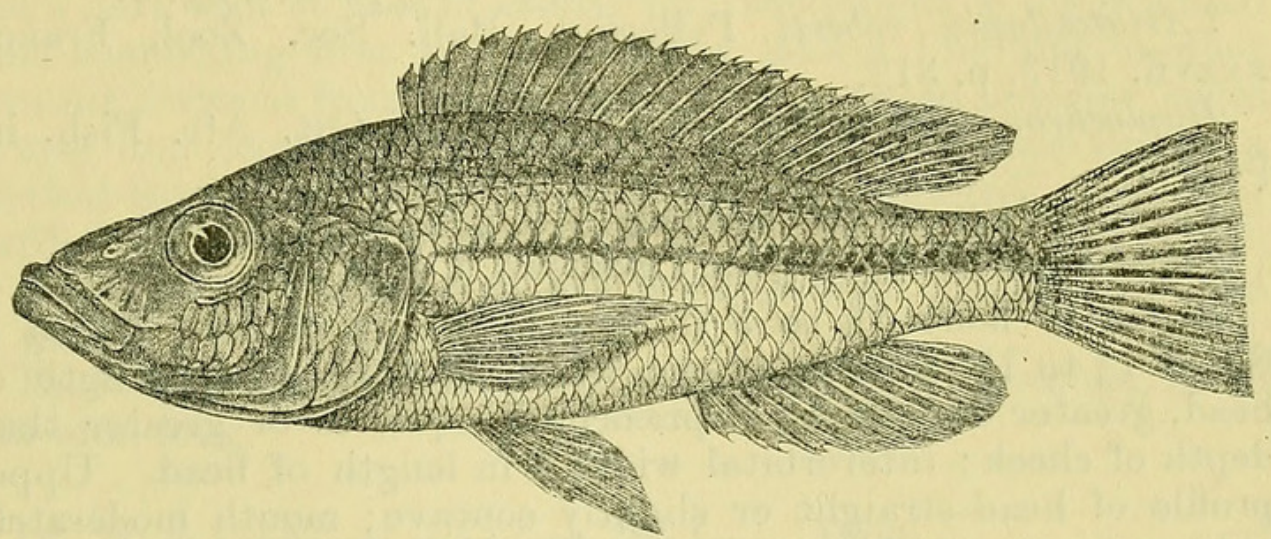

Haplochromis teniatus, sp. $\mathrm{n}$.

longest, $\frac{1}{3}$ length of head; longest soft rays less than half length of head. Anal III 9-10; third spine stronger than and as long as last dorsal. Pectoral $\frac{2}{3}$ length of head. Caudal truncate. Caudal peduncle $1 \frac{1}{2}$ as long as deep. 31 or 32 scales in a longitudinal series, 6 from origin of dorsal to lateral line. Silvery, back darker; an opercular spot; a dark band along middle of side, another above lateral line; dorsal and caudal with small spots.

Lake Victoria.

Two specimens, 95 and $115 \mathrm{~mm}$. long, from Entebbe (Degen) and Kavirondo Bay (Alluaud).

16. Haplochromis martini Bonleng., 1906.

Tilapic martini (part.) Bouleng. Cat. Afr. Fish. iii. p. 239, fig. 158.

Depth of body $2 \frac{2}{3}$ to 3 in length, length of head $2 \frac{3}{4}$ to 3 . Upper profile of head convex; snout shorter than diameter of eye, which is $2 \frac{2}{3}$ to 3 in length of head, greater than interorbital width, twice depth of præorbital. Lower jaw a little projecting; maxillary extending to below anterior $\frac{1}{3}$ of eye ; teeth in 3 ог 4 series, cuspidate, 50 to 70 in outer series of upper jaw. 4 or. 5 series of scales on cheek. 8 or 9 gill-rakers on lower part of anterior arch. Pharyngeal teeth small. 33 seales in a longitudinal series, 6 from origin of dorsal to lateral line. Dorsal XVXVI 8-9; last spine $\frac{1}{3}$ length of head. Anal III 8-9; third spine as long as last dorsal. Pectoral as long as head, extending 
to above anterior part of anal. Caudal truncate. Caudal peduncle $1 \frac{1}{3}$ to $1 \frac{1}{2}$ as long as deep. A blackish opercular spot; a blackish stripe from head to caudal fin, a second above lateral line.

Three of the types, 100-110 mm. long, from Bunjako.

17. Haplochromis nigrescens Pellegrin, 1909.

Astatotilapia nigrescens Pellegrin, Bull. Soc. Zool. France, xxxiv. p. 157, and Mém. xxii. 1910, p. 292, pl. xiv. fig. 3.

? Astatotilapia roberti Pellegrin, Bull. Soc. Zool. France, xxxvii. 1913 , p. 312.

Haplochromis percoides (part.) Bouleng. Cat. Afr. Fish. iii. p. 296.

Paratilapia parvidens Bouleng. t. c. p. 323, fig. 215.

Paratilapia serranus (part.) Bouleng. t. c. p. 334.

Depth of body $2 \frac{3}{5}$ to 3 in length, length of head $2 \frac{2}{3}$ to 3 . Snout $1 \frac{1}{3}$ to $1 \frac{2}{3}$ diameter of eye, which is 4 to $4 \frac{2}{3}$ in length of head, greater than depth of præorbital, equal to or greater than depth of cheek; interorbital width 4 in length of head. Upper profile of head straight or slightly concave; mouth moderately oblique; præmaxillary pedicels extending to between anterior edges of orbits; maxillary extending to below anterior edge or anterior $\frac{1}{4}$ of eye; lower jaw usually a little projecting. Teeth conical, or outer bicuspid and inner tricuspid, in 3 to 5 series in upper jaw and 3 or 4 in lower, 40 to 55 in outer series of upper. jaw. Cheek with 4 series of scales. 8 or 9 gill-rakers on lower part of anterior arch. Pharyngeal teeth slender. 32 or 33 scales in a longitudinal series, 5 or 6 from first dorsal spine to lateral line. Dorsal XV-XVI 9-10; last spine from $\frac{1}{3}$ to nearly $\frac{1}{2}$ length of head. Anal III 8-9; third spine stronger than and nearly as long as last dorsal. Pectoral $\frac{3}{4}$ length of head, reaching: vent or origin of anal. Caudal truncate or subtruncate. Caudal peduncle 1 to $1 \frac{1}{3}$ as long as deep. Coloration uniform, or a dark lateral hand, or traces of 8 to 10 dark cross-bars; soft dorsal and caudal sometimes with series of spots.

Five specimens, 95 to $140 \mathrm{~mm}$. in total length, from the Victoria Nile and Jinja (Bayon).

18. Haplochromis flavipinnis Bouleng., 1906.

Haplochromis percoides (part.) Bouleng. Cat. Afr. Fish. iii. p. 296, fig. 201.

Pelmatochromis flavipinnis Bouleng. t. c. p. 418, fig. 286.

Depth of body 3 to $3 \frac{1}{3}$ in length, length of head $2 \frac{3}{4}$ to 3 . Snout $1 \frac{1}{3}$ to $1 \frac{2}{3}$ diameter of eye, which is 4 to 5 in length of head, equal to or greater than præorbital depth, from $\frac{2}{3}$ to a little greater than depth of cheek; interorbital width 5 in length of head. Head twice as long as broad; upper profile concave above the eyes ; mouth oblique; maxillary extending to below anterior edge of eye, or nearly; lower jaw projecting; teeth in 3 or 4 
series, outer conical or bicuspid, inner conical or tricuspid; 45 to 60 in outer series of upper jaw. Cheek with 4 to 6 series of scales. 8 or 9 gill-rakers on lower part of anterior arch. Pharyngeal teeth slender. 31 or 32 scales in a longitudinal series, 6 to 8 from first dorsal spine to lateral line. Dorsal XIV-XV 9-10; last spine $\frac{1}{3}$ length of head. Anal III 8-9; third spine as long: as or shorter than last dorsal. Pectoral $\frac{2}{3}$ to $\frac{3}{4}$ length of head, not extending to above anal. Caudal subtruncate. Caudal peduncle $1 \frac{1}{2}$ as long as deep. Four broad dark cross bars on body and a dark spot at base of caudal fin ; sometimes a longitudinal band connecting first two bars below lateral line and another running forward from caudal spot; a bar between anterior edges of eyes and sometimes another in front of it across snout; a vertical bar below eye and another running upwards and backwards from posterior edge of eye; an opercular spot; fins yellow, or dorsal and caudal dusky; one or two orange ocelli on anal fin in males.

Three specimens, types of the species and of $H$. percoides, 85 to $145 \mathrm{~mm}$. long.

\section{Haplochromis microdon Bouleng., 1906.}

Tilapia lacrimosa (part.) Bouleng. Cat. Afr. Fish. iii. p. 234.

Haplochromis stanleyi (part.) Bouleng. t. c. p. 296, fig. 200.

Paratilapia serranus (part.) Bouleng. t. c. p. 334.

Pelnatochromis microdon Bouleng. t. c. p. 412, fig. 282.

Depth of body 3 to $3 \frac{1}{4}$ in length, length of head about 3 . Upper profile of head straight or slightly concave; snout from a little shorter than to $1 \frac{1}{3}$ as long as diameter of eye, which is 3 to 4 in length of head, greater than depth of præorbital, equal to or greater than depth of cheek; interorbital width $3 \frac{1}{2}$ to 4 in length of head. Nouth oblique; lower jaw projecting; maxillary reaching vertical from anterior edge of eye; teeth in 3 or 4 series in upper jaw, 2 to 4 in lower, 40 to 70 in outer series of upper jaw. 3 or 4 series of scales on cheek. 11 or 12 gill-raker's on lower part of anterior arch, the posterior much expanded. 30 to 33 scales in a longitudinal series, $4 \frac{1}{2}$ to 6 between first dorsal spine and lateral line. Dorsal XIV-XV 8-10; last spine $\frac{1}{3}$ to $\frac{2}{5}$ length of head; longest soft rays $\frac{1}{2}$ to $\frac{3}{4}$ length of head. Anal. III 8-9; last spine as long as or a little shorter and stronger than last of dorsal. Pectoral as long as or a little shorter than head, reaching anal. Caudal truncate or slightly emarginate. Caudal peduncle $1 \frac{1}{3}$ to $1 \frac{2}{3}$ as long as deep. Silvery or greyish, back olivaceous or brownish; sides with or without dark cross-bars and a dark lateral band; males with a dark bar. below eye, blackish pelvic fins and ocellar spots on anal.

\section{Lake Victoria.}

The specific name refers to the fact that the type, a specimen of $175 \mathrm{~mm}$., has very small teeth; this I believe to be due to malformation of the lower jaw, which does not bite against the 
upper; in all other characters it agrees with seven specimens of 80 to $140 \mathrm{~mm}$., including the type of $H$. stanleyi figured by Boulenger.

20. Haplochromis guiarti Pellegrin, 1905.

Tilapia griiarti Pellegr. Mém. Soc. Zool. France, xvii. p. 184, pl. xvi. fig. 1 .

Tilapia perrieri Pellegr. ib. xxii. 1910, p. 295, pl. xiv. fig. 4. Tilapia pallida (part.) Bouleng. Cat. Afr. Fish. iii. p. 232.

Paratilapia longirostris (part.) Bouleng. t. c. p. 332.

Paratilapia serranus (part.) Bouleng. t. c. p. 334, fig. 225.

Paratilapia guiarti Bouleng. t. c. p. 336, fig. 226.

Depth of body 3 to 4 in length, length of head 3 to $3 \frac{1}{3}$. Snout from a little shorter than to twice diameter of eye, which is 3 (young) to $5 \frac{1}{2}$ in length of head, in adult equal to or less than depth of cheek and equal to or not much greater than depth of praorbital; interorbital width $3 \frac{1}{3}$ to $4 \frac{1}{4}$ in length of head. Lower jaw more or less distinctly projecting; maxillary nearly or quite reaching vertical from anterior edge of eye, sometimes a little beyond; teeth cuspidate in young, conical in adult, in 3 to 5 series, 36 to 70 in outer series of upper jaw. 3 to 5 series of scales on cheek. 9 to 11 gill-rakers on lower part of anterior arch. Pharyngeal teeth slender. 32 to 34 scales in a longitudinal series, 6 or 7 from origin of dorsal to lateral line. Dorsal XV-XVII 8-10; last spine from $\frac{1}{4}$ to more than $\frac{2}{5}$ length of head. Anal III 8-10; third spine strouger and as long as or a little shorter than last dorsal. Pectoral from $\frac{2}{3}$ to nearly as long as head, reaching vent or origin of anal. Caudal truncate or very slightly emarginate, sometimes rounded below. Caudal peduncle $1 \frac{1}{2}$ to 2 as long as deep. Silvery or golden on sides, back darker; faint dark cross-bars sometimes present; often a blackish band from opercular spot to base of caudal and a second above lateral line; soft dorsal and caudal usually spotted; anal with ocelli in males.

Numerous examples up to $225 \mathrm{~mm}$. in total length.

21. Haplochromis serranus Pfefrer, 1896.

Hemichromis serranus Pfeffer, Thierw. O.-Afr. Fische, p. 23.

Pelmatochromis speliii (part.) Bouleng. Cat. Afr. Fish. iii.p. 416.

Depth of body $2 \frac{2}{3}$ to $3 \frac{1}{5}$ in length, length of head $2 \frac{3}{5}$ to $2 \frac{4}{5}$. Head 2 to $2 \frac{1}{2}$ as long as broad; upper profile straight. Snout $1 \frac{1}{3}$ to nearly twice diameter of eye, which is 4 to 5 in length of head, equal to or greater than præorbital depth, equal to or less than depth of cheek; interorbital width 4 to $4 \frac{2}{3}$ in length of head. Mouth moderately oblique; maxillary reaching vertical from anterior margin of eye ; lower jaw projecting; teeth conical, or inner tricuspid, in 3 to 5 series in upper jaw and 2 to 4 in lower, 40 to 80 in outer series of upper jaw. 5 series of scales on cheek. 8 or 9 gill-rakers on lower part of anterior arch. Pharyngeal 
teeth slender. 31 to 33 scales in a longitudinal series, 7 or 8 from origin of dorsal to lateral line; pectoral scales very small. Dorsal XV-XVI 9-10; last spine longest, less (adult) or more (young) than $\frac{1}{3}$ length of head ; longest soft rays $\frac{1}{2}$ to $\frac{3}{5}$ length of head. Anal III 8-9; third spine stronger and a little shorter than last dorsal. Pectoral $\frac{2}{3}$ to $\frac{3}{4}$ length of head, nearly or quite reaching anal; pelvics reaching vent or origin of anal. Caudal truncate or subtruncate. Caudal peduncle a little longer than deep. A dark opercular spot, usually a more or less distinct dark band from eye to caudal fin, another above lateral line, and a dark stripe at base of dorsal ; traces of dark cross-bars, sometimes a dark bar below eye; dorsal and caudal sometimes with series of small dark spots. Pelvics and anal pale or dusky, sometimes with ocelli on posterior part of anal.

Four specimens, 125 to $200 \mathrm{~mm}$. in total length.

\section{Haplochromis altigenis, sp. n. (Pl. I.)}

Paratilapia longirostris (part.) Bouleng. Cat. Afr. Fish. iii. p. 332 .

Pelmatochromis spekii (part.) Bouleng. t. c. p. 417.

Depth of body 3 in length, length of head $2 \frac{2}{3}$ to $2 \frac{3}{4}$. Head 2 to $2 \frac{1}{4}$ as long as broad; upper profile convex. Snout more than twice as long as diameter of eye, which is $5 \frac{2}{3}$ to 6 in length of head, less than præorbital depth and little more than $\frac{1}{2}$ depth of cheek ; interorbital width $4 \frac{1}{3}$ to $4 \frac{1}{2}$ in length of head. Maxillary extending to below anterior margin of eye; lower jaw projecting; teeth conical, in 4 or 5 series in upper jaw and 3 or 4 in lower, 60 to 70 in outer series of upper jaw. 5 series of scales on cheek. 9 or 10 gill-rakers on lower part of anterior arch. Pharyngeal teeth all slender. 32 or 33 scales in a longitudinal series, 7 or 8 from origin of dorsal to lateral line. Pectoral scales very small. Dorsal XV 9-10; last spine longest, $\frac{1}{4}$ to $\frac{2}{7}$ length of head; longest soft rays less than $\frac{1}{2}$ length of head. Anal III 8-10; third spine stronger than last dorsal, $\frac{2}{9}$ to $\frac{1}{4}$ length of head. Pectoral $\frac{2}{3}$ length of head or less, reaching origin of anal or not. Caudal subtruncate. Caudal peduncle longer than deep. Silvery; back darker; a bar below eye; an opercular spot and a lateral band more or less distinct. Vertical fins dusky, soft dorsal and caudal with or without series of spots; pelvics blackish; 4 or 5 ocelli on posterior part of anal.

Two specimens, 220 and $235 \mathrm{~mm}$. in total length, from Bunjako. A specimen of $100 \mathrm{~mm}$. from Bulolo, L. Kioga, is not included in the description.

23. Haplochromis squamulatus, nom. n.

Paratilapia pectoralis (not C'tenochromis pectoralis Pfeff.) Bouleng. Ann. Mus. Genov. 1911, p. 66, pl. i. fig, 2, and Cat. Afr. Fish. iii. p. 339, fig. 229.

Closely related to $H$. serranus and $H$. altigenis, with the snout 
more convex than the former and the præorbital narrower than the latter. 6 or 7 series of scales on cheek.

Total length $185 \mathrm{~mm}$. Ripon Falls.

\section{Haplochromis bayoni Bouleng., 1909.}

Paratilapia bayoni Bouleng. Cat. Afr. Fish. iii. p. 337, fig. 227.

Depth of body $3 \frac{1}{3}$ in length, length of head $2 \frac{4}{5}$. Snout decurved, a little more than twice diameter of eye, which is $5 \frac{1}{2}$ in length of head, equal to depth of præorbital, less than depth of cheek; interorbital width $4 \frac{1}{2}$ in length of head. Mouth moderately oblique ; lower jaw projecting ; maxillary not extending to below eye; teeth conical, in 4 series in upper jaw, 3 in lower; outer teeth rather strong, set well apart. 4 series of scales on cheek. 9 gill-rakers on lower part of anterior arch. Pharyngeal teeth slender. 32 scales in a longitudinal series, 6 from origin of dorsal to lateral line. Dorsal XVI 10 ; last spine $\frac{2}{7}$ length of head. Anal III 8; third spine $\frac{1}{4}$ head. Pectoral $\frac{5}{7}$ length of head, not reaching anal; pelvics reaching origin of anal. Caudal subtruncate. Caudal peduncle longer than deep. An opercular spot.

Here described from one of the types, probably a female, 160 $\mathrm{mm}$. long. The figured specimen, a male of $180 \mathrm{~mm}$., differs in having the first pelvic ray produced into a long filament and in the presence of two ocelli on the anal fin.

\section{Haplochromis macrodon, sp. n. (Text-fig. 4.)}

Pelmatochromis spekii (part.) Bouleng. Cat. Afr. Fish. iii.p. 417.

Depth of body 3 in length, length of head $2 \frac{2}{3}$ to $2 \frac{3}{4}$. Upper profile of head somewhat concave. Snout $1 \frac{1}{2}$ to $1 \frac{3}{4}$ diameter of

Text-figure 4 ,

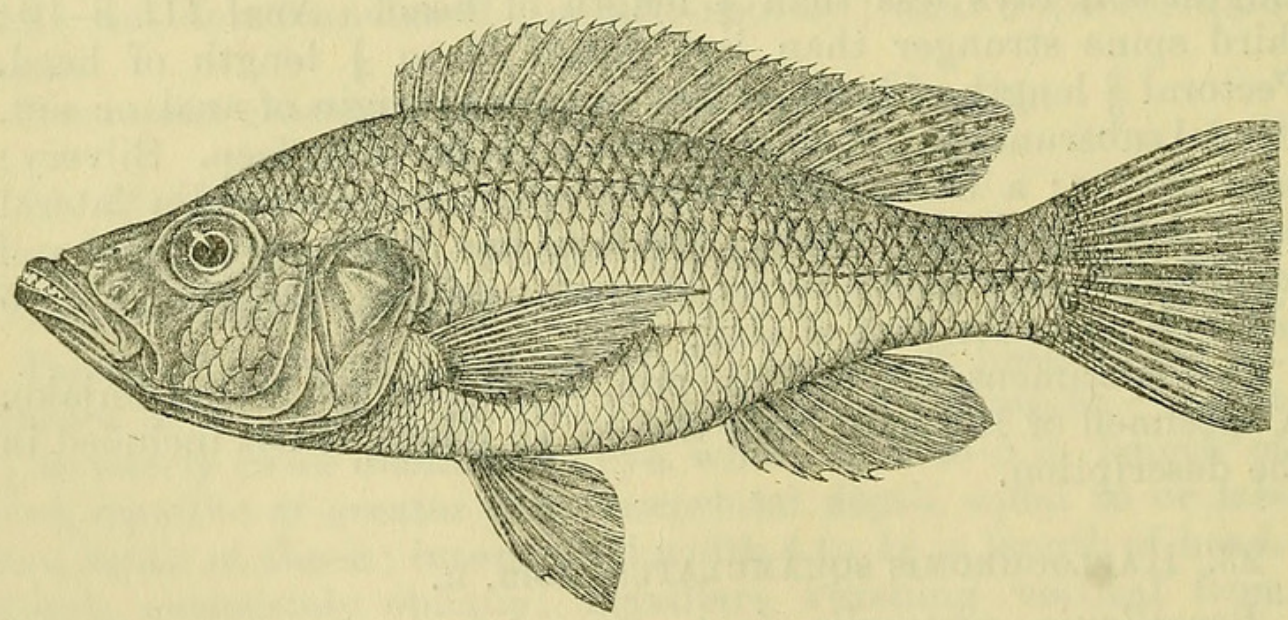

Haplochromis macrodon, sp. $\mathrm{n}$.

eye, which is $4 \frac{1}{2}$ to $4 \frac{2}{3}$ in length of head, a little greater than præorbital depth, equal to or a little less than depth of cheek; 
interorbital width 4 to $4 \frac{2}{3}$ in length of head. Mouth oblique; maxillary not extending to below eye; lower jaw projecting; teeth in 3 or 4 series in upper jaw, 2 or 3 in lower, outer conical, strong, and set well apart anteriorly. Cheek with 3 or 4 series of scales. 10 gill-rakers on lower part of anterior arch. Pharyngeal teeth slender. 31 to 33 scales in a longitudinal series, 5 or 6 from origin of dorsal to lateral line. Dorsal XV 9-10; last spine $\frac{1}{3}$ length of head or a little more. Anal III 8-10; third spine as long as or a little shorter than last dorsal. Pectoral $\frac{3}{4}$ head, reaching origin of anal. Caudal truncate. Caudal peduncle $1 \frac{1}{2}$ to $1 \frac{2}{3}$ as long as deep. Silvery; back darker; male with blackish pelvic fins and 3 ocelli on anal.

Three specimens, 135 to $155 \mathrm{~mm}$. long, from Entebbe and Munyonya.

\section{Haplochromis prognathus Pellegrin, 1905.}

Paratilapia prognatha (part.) Bouleng. Cat. Afr. Fish. iii.p. 333, fig. 224 .

Depth of body $2 \frac{4}{5}$ in length, length of head $2 \frac{3}{5}$. Head $2 \frac{3}{5}$ as long as broad; upper profile slightly concave. Snout twice diameter of eye, which is 5 in length of head, equal to præorbital depth or interorbital width, $\frac{3}{4}$ depth of cheek. Mouth moderately oblique; maxillary not extending to below eye; lower jaw strongly projecting; chin acute; teeth in 4 series in upper jaw, 3 in lower, some of the inner tricuspid, outer series conical; 60 in upper jaw, anterior moderately strong. 3 series of scales on cheek. 10 gill-rakers on lower part of anterior arch. 32 scales in a longitudinal series, 5 from origin of dorsal to lateral line. Dorsal XIV 10 ; last spine longest, $\frac{2}{7}$ length of head; longest soft rays $\frac{1}{2}$ length of head. Anal III 9 ; third spine stronger than and as long as last dorsal. Pectoral $\frac{3}{4}$ length of head, extending to anal spines; pelvies reaching anal. Caudal truncate. Caudal peduncle $1 \frac{1}{4}$ as long as deep. Silvery; back darker; an opercular spot; a dark bar below anterior part of eye.

One of the types, $170 \mathrm{~mm}$. long, from Kavirondo Bay. A specimen of $80 \mathrm{~mm}$. from Entebbe (Degen) seems to belong to this species.

\section{Haplochromis maculipinna Pellegr., 1913. (Text-fig. 5.)}

Paratilapia maculipinna Pellegr. Bull. Soc. Zool. France, xxxvii. p. 311.

Paratilapia prognatha (part.) Bouleng. Cat. Afr. Fish. iii. p. 333.

Depth of body equal to length of head, nearly 3 in length of fish. Head $2 \frac{1}{4}$ as long as broad ; profile slightly concave. Snout $1 \frac{1}{3}$ diameter of eye, which is 4 in length of head, greater than præorbital depth, equal to depth of cheek; interorbital width $4 \frac{1}{2}$ in length of head. Mouth oblique; lower jaw strongly projecting; maxillary not quite extending to below eye: teeth triserial, some

Proc. Zool. Soc.-1922, No. XII. 
of the inner tricuspid, outer series conical, 56 in upper jaw. 3 or 4 series of scales on cheek. 11 gill-rakers on lower part of anterior arch. 33 scales in a longitudinal series, 7 from origin of dorsal to lateral line. Dorsal XV 9 ; last spine longest, $\frac{1}{3}$ length of head; longest soft rays $\frac{1}{2}$ length of head. Anal III 8 ; third spine stronger than last dorsal, $\frac{1}{4}$ length of head. Pectoral $\frac{5}{6}$ length of head, extending to origin of anal; pelvics reaching

\section{Text-figure 5 .}

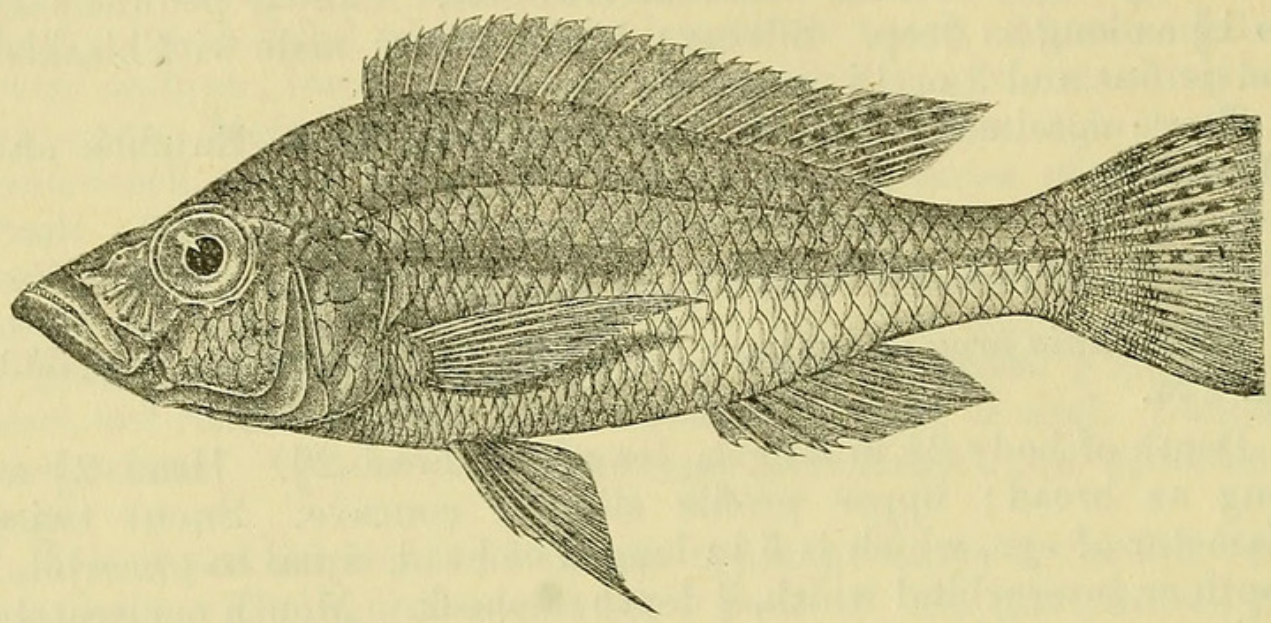

Haplochromis maculipinna.

anal. Caudal truncate. Caudal peduncle $1 \frac{2}{3}$ as long as deep. Silvery; back darker ; an opercular spot and a lateral band ; dark spots on dorsal and caudal.

A specimen of $180 \mathrm{~mm}$. from Bunjako.

The type, $156 \mathrm{~mm}$. long, is described as having the eye $3 \frac{1}{5}$ in length of head.

\section{Haplochromis dichrourus, sp. n. (Text-fig. 6.)}

Paratilapia serranus (part.) Bouleng. Cat. Afr. Fish. iii. p. 334.

Depth of body $3 \frac{1}{4}$ in length, length of head $2 \frac{2}{3}$. Snout $1 \frac{3}{4}$ diameter of eye, which is 5 in length of head, equal to interorbital width, greater than depth of præorbital, less than depth of cheek. Mouth moderately oblique; præmaxillary pedicels ending above nostril; maxillary extending to below anterior edge of eye; lower jaw strongly projecting; teeth in 3 series, outer conical, some inner tricuspid, 50 in outer series of upper jaw. 4 or 5 series of scales on cheek. 9 gill-rakers on lower part of anterior arch. Pharyngeal teeth slender. Dorsal XVI 9; last spine longest, less than $\frac{1}{3}$ length of head; longest soft rays less than $\frac{1}{2}$ length of head. Anal III 8 ; third spine $\frac{2}{7}$ length of head. Pectoral a little less than $\frac{3}{4}$ length of head, not quite reaching anal. Caudal subtruncate. Caudal peduncle a little longer than deep. 33 scales in a longitudinal series, 6 from first dorsal spine to lateral line, 5 or 6 between pectoral and pelvic fins. Silvery; 
back darker; dark spots on snout and above and below eye; an opercular spot; belly dusky; dorsal and upper half of caudal

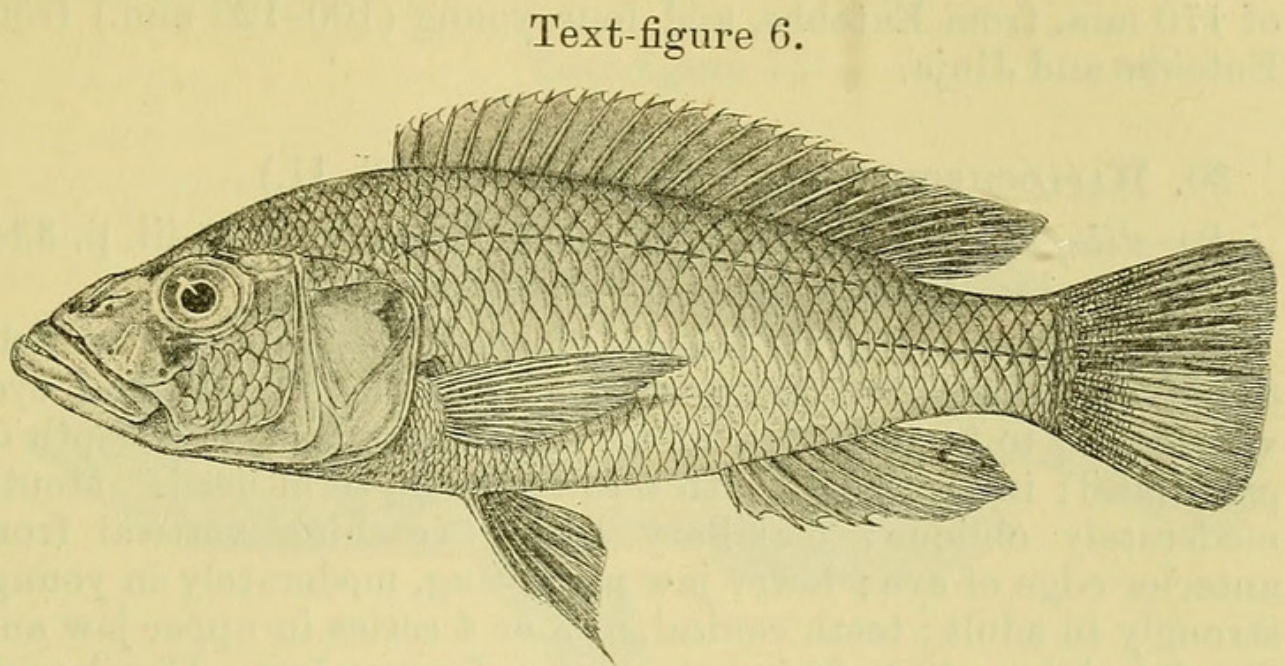

Haplochromis dichrourus, sp. n.

brown, anal and lower half of caudal bright red; an ocellus on posterior part of anal; pelvics blackish.

Buganga, L. Victoria (Degen).

A single specimen, $135 \mathrm{~mm}$. in length.

29. Haplochromis spekit Bouleng., 1906.

Pelmatochromis spekii (part.) Bouleng. Cat. Afr. Fish. iii. p. 417, fig. 285.

Depth of body $2 \frac{1}{2}$ to 3 in length, length of head $2 \frac{3}{5}$ to $2 \frac{3}{4}$. Head $2 \frac{1}{4}$ to $2 \frac{2}{5}$ as long as broad; upper profile straight or slightly concave. Snout $1 \frac{1}{3}$ to twice diameter of eye, which is 4 to $5 \frac{1}{2}$ in length of head, greater or less than præorbital depth, 1 to $1 \frac{2}{3}$ in depth of cheek; interorbital width 4 (adult) to 5 (young) in length of head. Maxillary extending to below anterior $\frac{1}{4}$ of eye ; lower jaw strongly projecting; teeth conical (adult) or outer bicuspid and inner tricuspid (young), in 3 to 5 series in upper jaw, 2 to 4 in lower; 40 to 60 in outer series of upper jaw. Cheek with 4 or 5 series of scales. 9 gill-rakers on lower part of anterior arch. Pharyngeal teeth slender. 31 or 32 scales in a longitudinal series, 5 or 6 from origin of dorsal to lateral line. Dorsal XV $9-10$; last spine longest, $\frac{1}{3}$ (adult) to $\frac{2}{5}$ (young) length of head ; longest soft rays a little more than $\frac{1}{2}(q)$ or $\frac{2}{3}(\delta)$ length of head. Anal III 8-10; third spine $\frac{2}{7}$ to $\frac{1}{3}$ length of hend, stronger than last dorsal. Pectoral $\frac{3}{4}$ to $\frac{7}{8}$ length of head, reaching origin of anal or beyond; pelvics reaching origin or anterior part of anal. Caudal rounded or subtruncate. Caudal peduncle $1 \frac{1}{5}$ to $1 \frac{1}{3}$ as long as deep. Silvery; back darker; a dark opercular spot; usually a dark lateral band from eye backwards, extending on caudal fin ; a dark bar below anterior part of eye $\left(\sigma^{*}\right)$; soft dorsal and caudal 
sometimes spotted; pelvics and anal yellow (ㅇ) or pelvics blackish and anal greyish, with several ocelli posteriorly $\left(\delta^{\circ}\right)$.

A male of $235 \mathrm{~mm}$. from Bunjako (specimen figured); a female of $170 \mathrm{~mm}$. from Entebbe, and four young (100-120 mm.) from Entebbe and Jinja.

30. Haplochromis serranoides, sp. n. (Pl. II.)

Paratilapia serranus (part.) Bouleng. Cat. Afr. Fish. iii. p. 334. Pelmatochromis spekii (part.) Bouleng. t. c. p. 417.

Depth of body equal to length of head, $2 \frac{3}{4}$ in length of fish. Snout with straight upper profile, $1 \frac{1}{3}$ to twice diameter of eye, which is $3 \frac{3}{4}$ to $5 \frac{1}{2}$ in length of head, in adult less than depth of præorbital; interorbital width 4 to $4 \frac{1}{3}$ in length of head. Mouth moderately oblique; maxillary barely reaching vertical from anterior edge of eye ; lower jaw projecting, moderately in young, strongly in adult; teeth conical, in 3 or 4 series in upper jaw and 2 or 3 in lower, 40 to 60 in outer series of upper jaw. Cheek with 3 or 4 series of scales, once to 13 diameter of eye. 8 gill-rakers and 2 rudiments on lower part of anterior arch. Pharyngeal teeth slender. 32 scales in a longitudinal series, 5 or 6 from origin of dorsal to lateral line. Dorsal XVI 9-10; last spine $\frac{1}{3}$ to $\frac{2}{5}$ length of head. Anal III 10-11; third spine $\frac{1}{4}$ to more than $\frac{1}{3}$ head. Pectoral $\frac{3}{5}$ to $\frac{2}{3}$ length of head, reaching vent or origin of anal. Caudal subtruncate. Caudal peduncle as long as deep. Silvery or greyish; a dark opercular spot; spinous dorsal dusky; soft dorsal and anal dusky at the base, pale distally, the dark colour with a well-defined undulating margin; caudal dusky at base. Adult male with a blackish bar below the eye, blackish pelvic fins, and ocelli on the anal fin.

Three specimens, 95 to $220 \mathrm{~mm}$. in total length, from Lake Victoria (Delmé Radcliffe) and between L. Kioja and Murchison Falls (Melland).

\section{Haplochromis acutirostris, sp. n. (Text-fig. 7.)}

Paratilapia prognatha (part.) Bouleng. Cat. Afr. Fish. iii. p. 333.

Depth of body 3 to $3 \frac{1}{4}$ in length, length of head $2 \frac{3}{5}$ to $2 \frac{4}{5}$. Snout $1 \frac{1}{3}$ to 2 diameter of eye, which is 4 to $5 \frac{1}{3}$ in length of head, in adult less than depth of præorbital or cheek; interorbital width $4 \frac{1}{2}$ to 5 in length of head. Mouth oblique, anteriorly above level of eye ; lower jaw strongly projecting; maxillary extending to vertical from anterior edge of eye; teeth conical in adult, some cuspidate in young, in 3 or 4 series in upper jaw and 2 or 3 in lower, 40 to 50 in outer series of upper jaw. Cheek with 4 to 6 series of scales. 8 to 10 gill-rakers on lower part of anterior arch. Pharyngeal teeth slender. 31 to 33 scales in a longitudinal series, 5 or 6 from origin of dorsal to lateral line. Dorsal XV-XVI 8-10 ; last spine longest, $\frac{2}{5}$ or a little less than $\frac{2}{5}$ length of head. Anal III 8-10; third spine stronger and as long as and 
a little shorter than last dorsal. Pectoral $\frac{2}{3}$ length of head, nearly or quite reaching anal. Caudal rounded or subtruncate. Caudal peduncle longer than deep. An opercular spot and a

Text-figure 7.

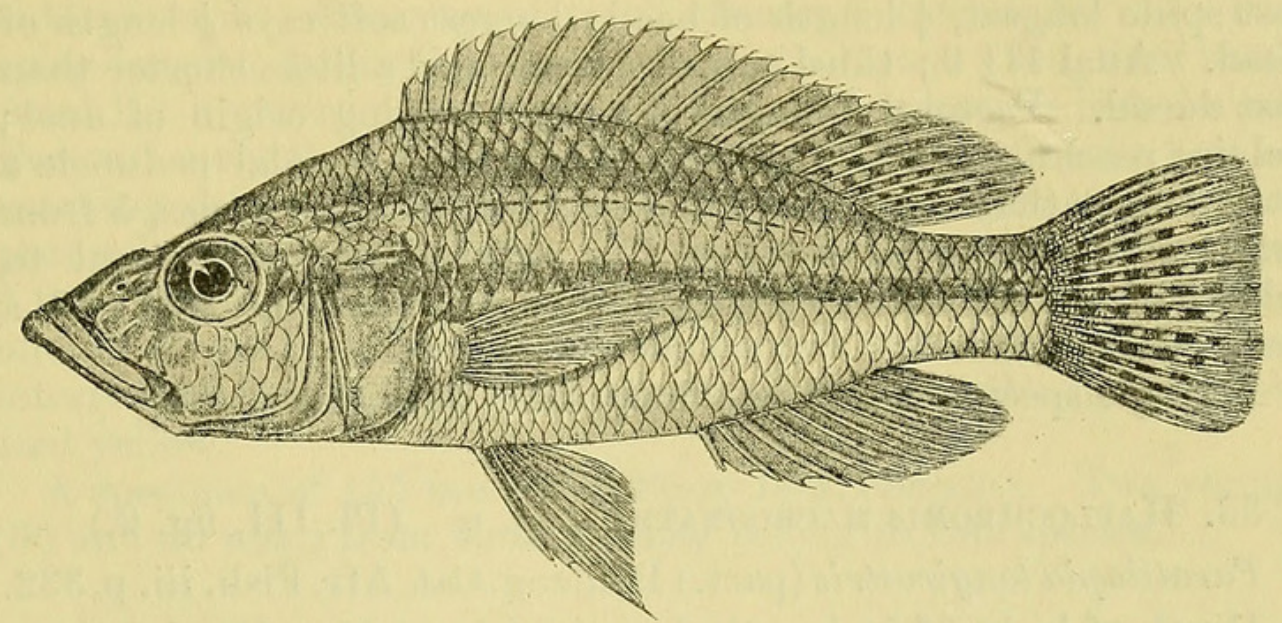

Haplochromis acutirostris, sp. n.

lateral band; vertical fins dusky, the soft dorsal and caudal sometimes with clear spots; adult male with blackish bar below eye, blackish pelvic fins and ocelli on anal fin.

Four specimens, 90 to $180 \mathrm{~mm}$. in total length, from Bunjako (Degen) and L. Salisbury (Jackson).

\section{Haplochromis plagiostoma, sp. n. (Text-fig. 8.)}

Paratilapia longirostris (part.) Bouleng. Cat. Afr. Fish. iii. p. 332.

Depth of body 3 in length, length of head $2 \frac{3}{4}$. Head a little more than twice as long as broad; upper profile straight. Snout

Text-figure 8.

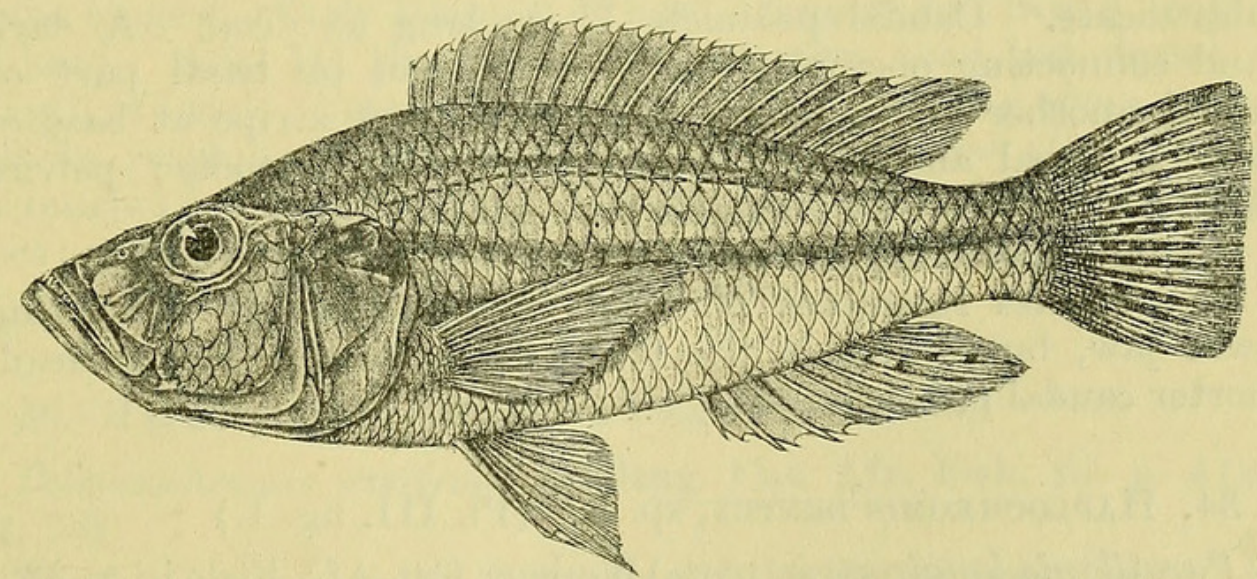

Haplochromis plagiostoma, sp. $\mathrm{n}$.

$1 \frac{1}{2}$ diameter of eye, which is $4 \frac{1}{2}$ in length of head, slightly greater than præorbital depth, $\frac{2}{3}$ depth of cheek; interorbital width $4 \frac{1}{2}$ 
in length of head. Mouth very oblique; lower jaw strongly projecting ; maxillary not extending to below eye ; teeth conical, 4 series in upper jaw, 3 in lower; outer series regular, about 50 in upper jaw. 4 series of scales on cheek. 8 gill-rakers on lower part of anterior arch. Pharyngeal teeth slender. Dorsal XV 9 ; last spine longest, $\frac{1}{3}$ length of head; longest soft rays $\frac{1}{2}$ length of head. Anal III 9; third spine stronger and a little shorter than last dorsal. Pectoral $\frac{3}{4}$ length of head, reaching origin of anal; pelvics reaching vent. Caudal subtruncate. Caudal peduncle a little longer than deep. 30 scales in a longitudinal series, 5 from origin of dorsal to lateral line, 7 or 8 from base of pectoral to middle of chest. Silvery; back darker, an opercular spot and a dark lateral band.

A single specimen, $140 \mathrm{~mm}$. long, from Bunjako.

\section{Haplochromis macrognathus, sp. n. (Pl. III. fig. 2.)}

Paratilapia longirostris (part.) Bouleng. Cat. Afr. Fish. iii. p. 332.

Depth of body $3 \frac{3}{4}$ in length, length of head $2 \frac{3}{5}$. Head 3 times as long as broad; upper profile nearly straight. Snout as long as postorbital part of head, $2 \frac{1}{2}$ diameter of eye, which is 6 in length of head, a little less than præorbital depth, $\frac{3}{5}$ depth of cheek; interorbital width $5 \frac{1}{2}$ in Jength of head. Maxillary extending to vertical from anterior margin of eye ; lower jaw very strongly projecting, the anterior teeth exposed to the innermost series; teeth conical, in 5 series in upper jaw and 4 in lower, about 80 in outer series of upper jaw. 5 series of scales on cheek. 9 gill-rakers on lower part of anterior arch. Pharyngeal teeth slender. 32 scales in a longitudinal series, 6 from origin of dorsal to lateral line. Dorsal XV 10 ; last spine longest, $\frac{2}{7}$ length of head; longest soft rays $\frac{2}{5}$ length of head. Anal III 9 ; third spine stronger than last dorsal, $\frac{1}{4}$ length of head. Pectoral $\frac{2}{3}$ length of head, not reaching anal; peivics reaching vent. Caudal subtruncate. Caudal peduncle $1 \frac{1}{4}$ as long as deep. A dark band connecting opercular spot with a spot on basal part of caudal, another above lateral line and a dark stripe at base of dorsal; dorsal and caudal with series of dark spots; pelvics blackish; two ocelli on posterior part of anal.

A single specimen, $195 \mathrm{~mm}$. in total length, from Bunjako.

This species resembles $H$. mento in the strongly projecting lower jaw, but differs in the much larger mouth, longer head, shorter caudal peduncle, etc.

\section{Haplochronis dentex, sp. n. (Pl. III. fig. 1.)}

Paratilapia longirostris (part.) Bouleng. Cat. Afr. Fish.iii. p.332.

Depth of body $3 \frac{5}{6}$ in length, length of head $2 \frac{5}{6}$. Head $2 \frac{1}{2}$ as long as broad; upper profile slightly convex. Snout nearly twice diameter of eye, which is 5 in length of head, equal to præorbital depth, less than depth of cheek; interorbital width 4 
in length of head. Snout decurved; mouth little oblique; maxillary not far short of vertical from anterior margin of eye; lower jaw strongly projecting, with the anterior teeth exposed. Teeth conical, triserial, outer strong and set well apart anteriorly. 4 or 5 series of scales on cheek. 10 gill-rakers on lower part of anterior arch. Pharyngeal teeth slender. Dorsal XV 10; last spine longest, $\frac{1}{4}$ length of head ; longest soft rays $\frac{1}{2}$ length of head. Anal III 9 ; third spine stronger than and as long as last dorsal. Pectoral more than $\frac{2}{3}$ length of head, ending above vent; pelvics reaching origin of anal. Caudal slightly emarginate. Caudal peduncle $1 \frac{2}{3}$ as long as deep. 34 scales in a longitudinal series, 5 from origin of dorsal to lateral line, 10 from base of pectoral to middle of chest. Silvery; back darker; an opercular spot and an interrupted lateral band; dorsal and caudal greyish ; pelvics and anal yellow.

A specimen of $155 \mathrm{~mm}$. from Sesse Isds. (Bayon). Two young (60 and $80 \mathrm{~mm}$.) from Entebbe may belong to this species.

\section{Haplochromis mento, sp. n.}

Paratilapia longirostris (part.) Bouleng. Cat. Afr. Fish. iii. p. 332 , fig. 223.

Depth of body $3 \frac{1}{2}$ in length, length of head $2 \frac{3}{4}$. Head $2 \frac{3}{4}$ as long as broad ; upper profile slightly convex. Snout $2 \frac{1}{2}$ diameter of eye, which is 6 in length of head, equal to præorbital depth, less than depth of cheek; interorbital width $4 \frac{1}{2}$ in length of head. Maxillary not nearly reaching vertical from anterior margin of eye; lower jaw strongly projecting, with the anterior teeth exposed; teeth conical, 5 series in upper jaw, 3 in lower, outer strong and set well apart anteriorly. 4 series of scales on cheek. 10 or 11 gill-rakers on lower part of anterior arch. Pharyngeal teeth slender. 34 scales in a longitudinal series, 6 or 7 from origin of dorsal to lateral line. Dorsal XVI 10; last spine longest, nearly $\frac{1}{3}$ length of head ; longest soft rays $\frac{2}{5}$ length of head. Anal III 10 ; third spine stronger than last dorsal, $\frac{1}{4}$ length of head. Pectoral $\frac{2}{3}$ length of head, ending above vent; pelvics reaching origin of anal. Caudal rounded (?). Caudal peduncle $1 \frac{3}{4}$ as long as deep. Silvery; back darker; an opercular spot; pelvics dusky; 3 ocelli on posterior part of anal.

A specimen of $210 \mathrm{~mm}$., from Bunjako.

36. Haplochromis cavifrons Hilgendorf, 1888.

Pelmatochromis cavifrons Bouleng. Cat. Afr. Fish. iii. p. 419, fig. 287.

Depth of body about 3 in length, length of head $2 \frac{1}{2}$ to $2 \frac{3}{4}$. Snout twice diameter of eye, which is 5 to $5 \frac{1}{2}$ in length of head, nearly equal to præorbital depth, $\frac{2}{3}$ depth of cheek; interorbital width 4 in length of head. Mouth very oblique; lower jaw strongly projecting; maxillary not quite reaching to below eye; 
teeth mostly conical, in 4 or 5 series in upper jaw, 3 or 4 in lower, 60 to 70 in outer series of upper jaw. 5 or 6 series of scales on cheek. 7 to 9 gill-rakers on lower part of anterior arch. 33 to 36 scales in a longitudinal series, 8 to 10 from origin of dorsal to lateral line. Dorsal XV-XVI 8-10; last spine $\frac{1}{3}$ head. Anal III 8-9; third spine $\frac{2}{7}$ head. Pectoral $\frac{3}{5}$ head, not reaching anal. Caudal rounded or subtruncate. Caudal peduncle $1 \frac{1}{4}$ to $1 \frac{1}{2}$ as long ais deep. Body with numerous small irregular dark spots.

Seven specimens, up to $200 \mathrm{~mm}$. long.

37. Haplochromis orthostoma, sp. n. (Text-fig. 9.)

Pelmatochromis spekii (part.) Bouleng. Cat. Afr. Fish. iii. p. 417 (1915).

Depth of body nearly equal to length of head, $2 \frac{3}{5}$ in length of fish. Head $2 \frac{1}{2}$ as long as broad; upper profile convex to above anterior part of eye, thence straight. Snout longer than diameter of eye, which is 5 in length of head, nearly equal to interorbital width or præorbital depth. Mouth very oblique; maxillary not quite reaching vertical from anterior edge of eye; lower jaw strongly projecting, more than $\frac{1}{2}$ length of head; teeth conical, triserial, about 60 in outer series of upper jaw. Cheek as deep

Text-figure 9.

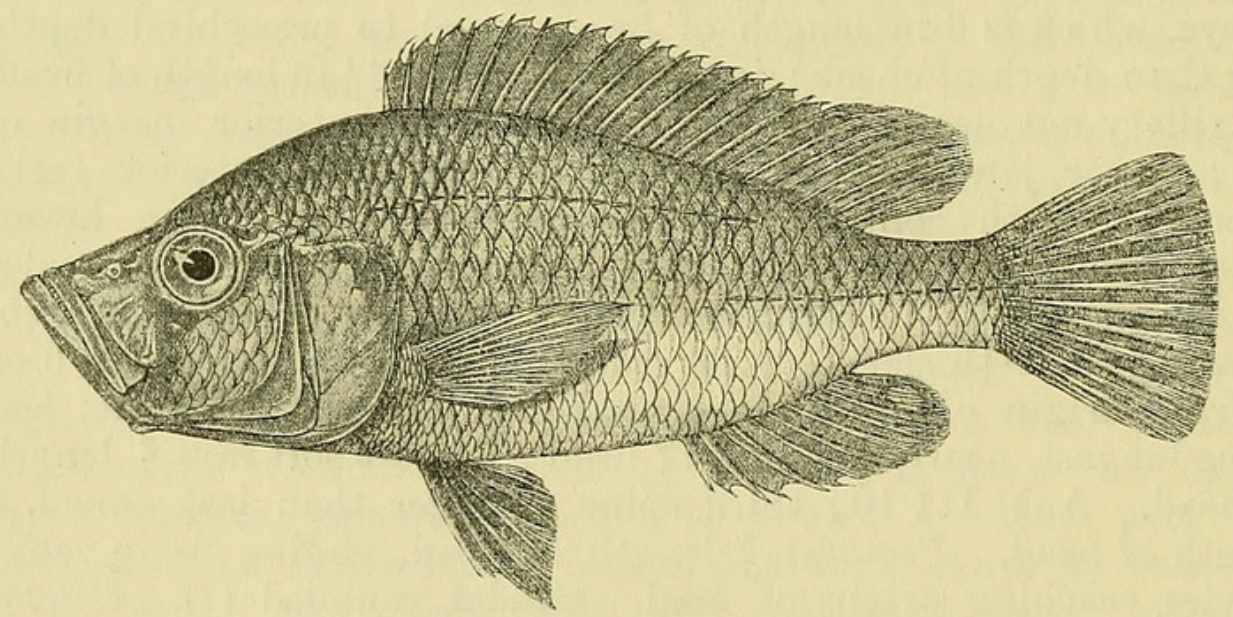

Haplochromis orthostoma, sp. n.

as long, with 4 or 5 series of scales. 9 gill-rakers on lower part of anterior arch. Pharyngeal teeth slender. 33 scales in a longitudinal series, 6 or 7 from origin of dorsal to lateral line. Dorsal XV 9 ; last spine longest, $\frac{2}{5}$ length of head. Anal III 8 ; third spine stronger than and nearly as long as last dorsal. Pectoral shorter than head, not reaching anal. Caudal rounded. Caudal peduncle $1 \frac{1}{2}$ as long as deep. Greyish; a dark bar below anterior part of eye; pelvic fins blackish; an ocellus on posterior part of anal.

A single specimen, $115 \mathrm{~mm}$. in total length, from Lake Salisbury. 
38. Haplochromis xenostoma, sp. n. (Text-fig. 10.)

Paratilapia prognatha (part.) Bouleng. Cat. Afr. Fish. iii. p. 333.

Depth of body $3 \frac{1}{2}$ to $3 \frac{3}{4}$ in length, length of head $2 \frac{7}{8}$ to 3 . Head $2 \%$ as long as broad; upper profile slightly concave. Snout $1 \frac{1}{2}$ to $1 \frac{2}{3}$ diameter of eye, which is $4 \frac{1}{2}$ to $4 \frac{2}{3}$ in length of head. greater than preorbital depth, nearly equal to depth of cheek; interorbital width $4 \frac{2}{3}$ in length of head. Mouth oblique; maxillary not extending to below eye; lower jaw very prominent, projecting upwards above end of snout; teeth in 3 series, inner tricuspid, outer conical or some bicuspid, 50 to 56 in upper jaw,

Text-figure 10.

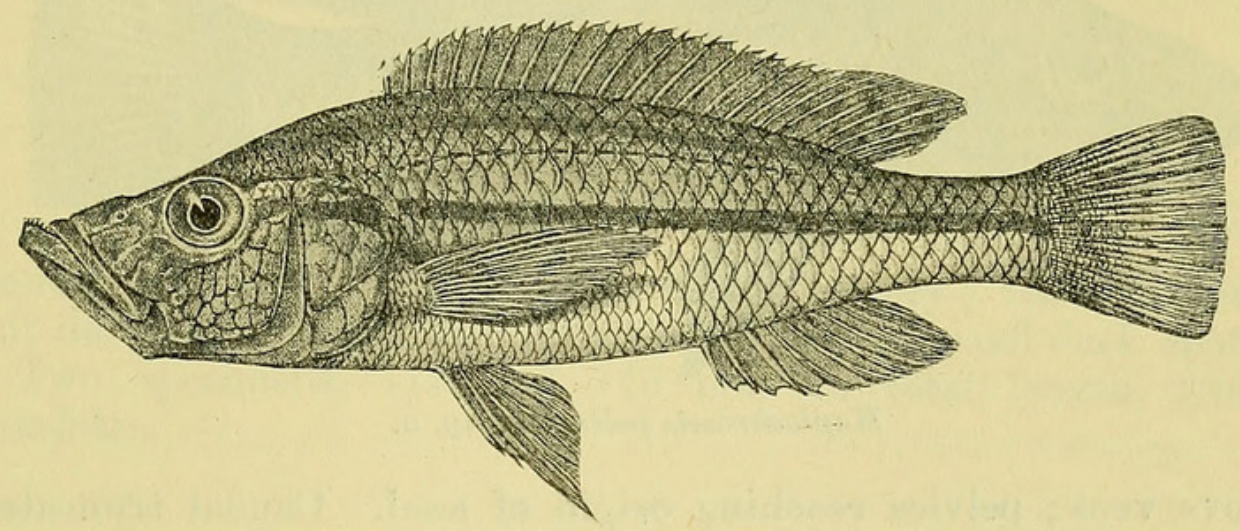

Haplochromis xenostoma, sp. $\mathrm{n}$.

4 series of scales on cheek. 9 gill-rakers on lower part of anterior arch. 33 scales in a longitudinal series, 6 from origin of dorsal to lateral line. Dorsal XVI 8-9 ; last spine longest, $\frac{2}{7}$ length of head; longest soft rays $\frac{2}{5}$ length of head. Anal III 8 ; third spine stronger than and as long as last dorsal. Pectoral $\frac{2}{3}$ to $\frac{3}{4}$ length of head, not reaching anal; pelvics nearly reaching vent. Caudal subtruncate. Caudal peduncle $1 \frac{1}{2}$ as long as deep. An opercular spot and a lateral band; small dark spots on soft dorsal and caudal.

Two specimens, 105 and $125 \mathrm{~mm}$. long, one collected by Sir H. H. Johnston, the other from Entebbe (Degen).

39. Haplochromis pellegrini, sp. n. (Text-fig. 11.)

Paratilapia prognatha (part.) Bouleng. Cat. Afr. Fish. iii. p. 333.

Depth of body $3 \frac{1}{2}$ in length, length of head $2 \frac{3}{4}$ to $2 \frac{4}{5}$. Head $2 \frac{2}{3}$ to $2 \frac{3}{4}$ as long as broad ; upper profile slightly concave. Snout $1 \frac{2}{3}$ diameter of eye, which is $4 \frac{2}{3}$ in length of head, greater than præorbital depth, equal to or a little less than depth of cheek, equal to interorbital width. Mouth oblique; maxillary not far short of vertical from anterior edge of eye; lower jaw strongly projecting, but not above end of snout; teeth conical, 4 series in 
upper jaw, 3 in lower, 60 in outer series of upper jaw. 3 or 4 series of scales on cheek. 8 or 9 gill-rakers on lower part of anterior arch. 32 scales in a longitudinal series, 6 or 7 from origin of dorsal to lateral line. Dorsal XIV 10 ; last spine longest, $\frac{1}{3}$ or a little more than $\frac{1}{3}$ length of head: longest soft rays $\frac{1}{2}$ length of head. Anal III 9 ; third spine $\frac{2}{7}$ or a little more than $\frac{2}{7}$ length of head. Pectoral $\frac{5}{7}$ length of head, extending to

\section{Text-figure 11.}

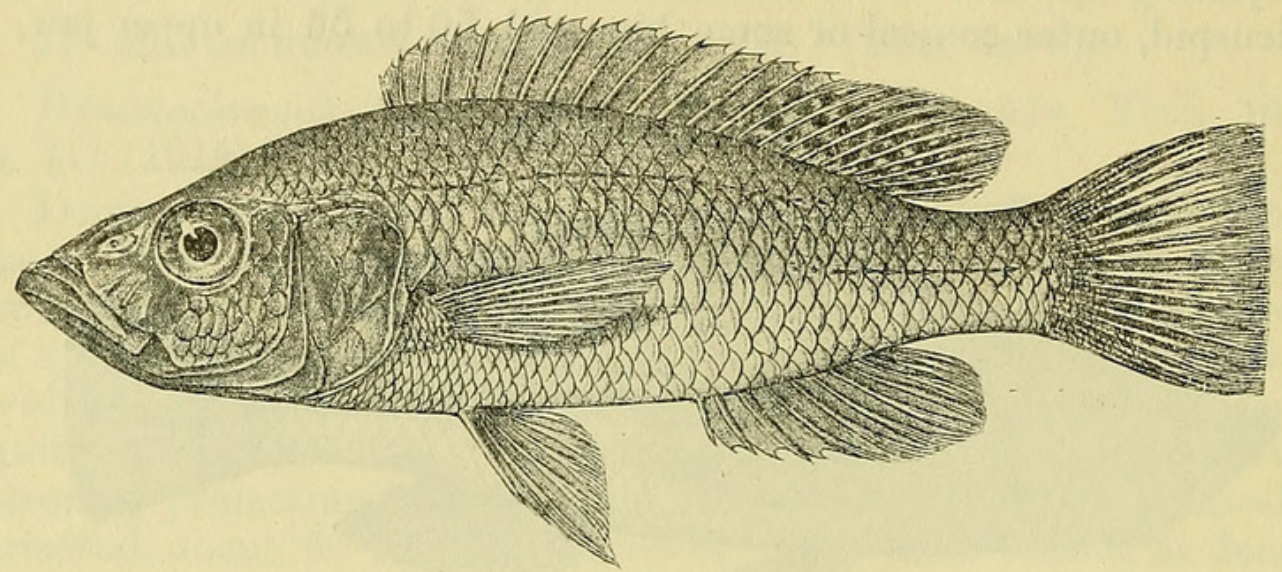

Haplochromis pellegrini, sp. $\mathrm{n}$.

above vent; pelvics reaching origin of anal. Caudal truncate. Caudal peduncle $1 \frac{1}{3}$ as long as deep. An opercular spot; small dark spots on dorsal and caudal; one specimen with 3 ocelli on posterior part of anal.

Two specimens, 125 and $130 \mathrm{~mm}$. long, from Entebbe (Degen).

Two others $(75 \mathrm{~mm}$.), from Entebbe, seem to belong to this species; they have XV 9 dorsal rays.

40. Haplochromis argenteus, sp. n. (Text-fig. 12.)

Paratilapia longirostris (part.) Bouleng. Cat. Afr. Fish. iii. p. 332.

Depth of body 3 to $3 \frac{1}{2}$ in length, length of head $2 \frac{1}{2}$ to $2 \frac{2}{3}$. Head 3 times as long as broad; upper profile slightly concave. Snout $1 \frac{3}{5}$ to $1 \frac{3}{4}$ diameter of eye, which is about $4 \frac{1}{2}$ in length of head, slightly greater than præorbital depth, equal to depth of cheek; interorbital width about 5 in length of head. Mouth oblique; lower jaw strongly projecting; maxillary not nearly reaching vertical from anterior margin of eye ; 3 series of teeth in upper jaw, 2 in lower, anterior inner teeth tricuspid, outer mostly conical, some lateral ones bicuspid ; 46 to 60 in outer series of upper jaw, the anterior rather strong. 3 or 4 series of scales on cheek. 8 or 9 gill-rakers on lower part of anterior arch. Pharyngeal teeth slender. 32 or 33 scales in a longitudinal series, 5 or 6 from origin of dorsal to lateral line. Dorsal XV 9-10; last 
spine longest, a little less than $\frac{1}{3}$ length of head. Anal III 9; third spine stronger than and about as long as last dorsal. Pectoral $\frac{3}{5}$ to $\frac{2}{3}$ length of head, reaching vent. Caudal truncate.

\section{Text-figure 12.}

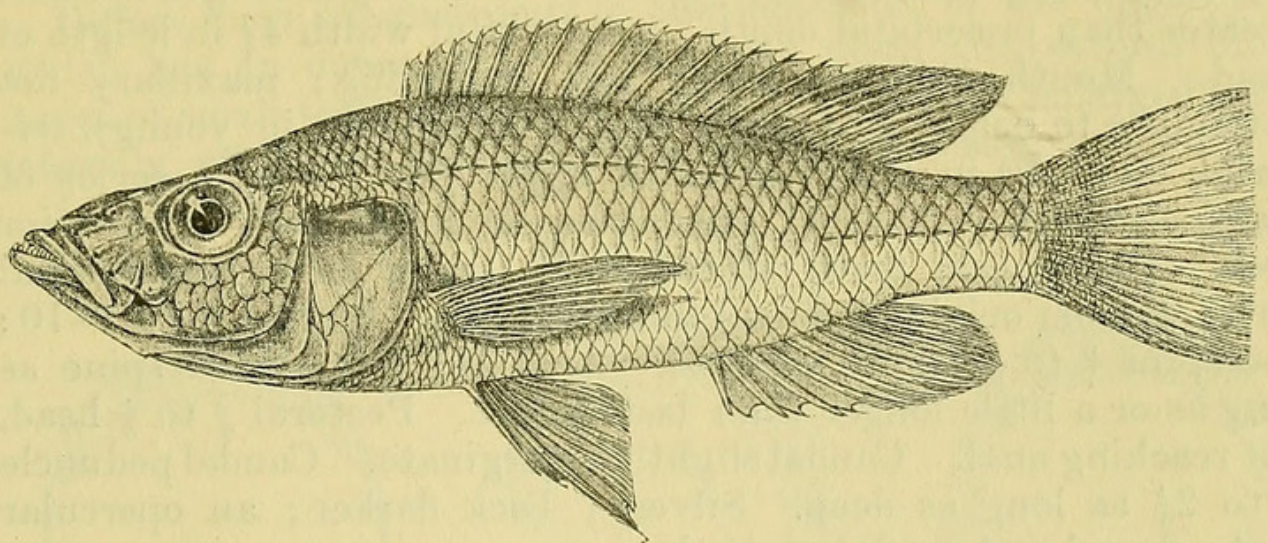

Haplochromis argenteus, sp. n.

Caudal peduncle $1 \frac{1}{2}$ as long as deep. Silvery; back darker; soft dorsal and caudal with or without series of small dark spots.

Two specimens, 115 and $140 \mathrm{~mm}$. in total length, from Bunjako.

41. Haplochromis longirostris Hilgend., 1888. (Pl. IV. fig. 2.)

Paratilapia longirostris (part.) Bouleng. Cat. Afr. Fish. iii. p. 332 .

Depth of body $3 \frac{1}{3}$ to $3 \frac{2}{3}$ in length, length of head $2 \frac{4}{5}$ to 3 . Head $2 \frac{2}{3}$ to $2 \frac{4}{5}$ as long as broad; upper profile straight or slightly concave. Snout $1 \frac{2}{3}$ to twice diameter of eye, which is $4 \frac{2}{3}$ to $5 \frac{1}{4}$ in length of head, equal to or a little more than præorbital depth, equal to or a little less than depth of cheek; interorbital width $4 \frac{1}{3}$ to $4 \frac{1}{2}$ in length of head. Mouth oblique; lower jaw projecting; maxillary not extending to below eye; teeth conical (inner tricuspid in young), 3 or 4 series in upper jaw, 2 or 3 in lower, 50 to 60 in outer series of upper jaw. 3 or 4 series of scales on cheek. 10 or 11 gill-rakers on lower part of anterior arch. Pharyngeal teeth slender. 33 scales in a longitudinal series, 6 or 7 from origin of dorsal to lateral line. Dorsal XV-XVI 9-10; last spine longest, $\frac{1}{4}$ to $\frac{1}{3}$ length of head. Anal III 9 ; third spine stronger than and as long as last dorsal. Pectoral $\frac{2}{3}$ to $\frac{3}{4}$ length of head, not reaching anal. Caudal truncate. Caudal peduncle nearly twice as long as deep. Silvery; back darker; an opercular spot; soft dorsal and caudal sometimes spotted.

Three specimens, 100 to $160 \mathrm{~mm}$. long. 
42. Haplochromis gracilicauda, sp. n. (Pl. IV. fig. 1.)

Paratilapia longirostris (part.) Bouleng. Cat. Afr. Fish. iii. p. 332 .

Depth of body 4 to $4 \frac{1}{4}$ in length, length of head 3 to $3 \frac{1}{3}$. Snout $1 \frac{1}{3}$ to $1 \frac{2}{3}$ diameter of eye, which is 4 to $4 \frac{2}{3}$ in length of head, greater than præorbital depth; interorbital width $4 \frac{1}{4}$ in length of head. Mouth oblique; lower jaw projecting; maxillary not extending to below eye; teeth conical (cuspidate in young), triserial, 50 to 60 in outer series of upper jaw. 3 or 4 series of scales on cheek. 10 or 11 gill-rakers on lower part of anterior arch. Pharyngeal teeth slender. 33 scales in a longitudinal series, 6 from origin of dorsal to lateral line. Dorsal XVI 9-10 ; last spine $\frac{2}{7}$ to $\frac{1}{3}$ length of head. Anal III 8-9; third spine as long as or a little longer than last dorsal. Pectoral $\frac{3}{4}$ to $\frac{4}{5}$ head, not reaching anal. Caudal slightly emarginate. Caudal peduncle 2 to $2 \frac{1}{4}$ as long as deep. Silvery; back darker; an opercular spot; dorsal and caudal spotted.

Two specimens, 105 and $150 \mathrm{~mm}$. long, from Bunjako and Entebbe.

43. Haplochromis xenodon Bouleng., 1911.

Bayonia xenodonta Bouleng. Cat. Afr. Fish. iii. p. 488, fig. 338.

Very near $H$. cinereus, distinguished principally by the dentition. Outer teeth few and large, compressed, with long anterior cusp directed inwards and posterior cusp very short or indistinct.

Total length $90 \mathrm{~mm}$.

44. Haplochromis obliquidens Hilgend., 1888.

Hemitilapia bayoni Bouleng. Cat. Afr. Fish. iii. p. 491, fig. 340.

? Hemitilapia materfamilias (Pellegrin, 1913), Bouleng. t, c. p. 341 .

Very near H. nuchisquamulatus. Teeth in 4 to 6 series, slender, distally expanded and compressed ; teeth of outer series enlarged, obliquely truncated.

Total length $138 \mathrm{~mm}$.

3. Astatoreochromis Pellegrin, 1904.

As Haplochromis, but with 4 to 6 anal spines.

L. Victoria.

Astatoreochromis alluaddi Pellegrin, 1904.

Haplochromis alluaudi Bouleng. Cat. Afr. Fish. iii. p. 305, fig. 206.

Near H. gestri, especially distinguished by the increased number 
of dorsal and anal spines and the large blunt pharyngeal teeth. Dorsal XVII-XIX 6-9. Anal IV-VI 6-9.

Total length $155 \mathrm{~mm}$.

\section{Macropleurodus, gen. n.}

Differs from Haplochromis in the dentition of the upper jaw, which has an outer series of enlarged teeth and several inner series of small teeth anteriorly and 3 or 4 series of enlarged teeth laterally, which are exposed when the mouth is shut.

L. Victoria.

Text-figure 13 .
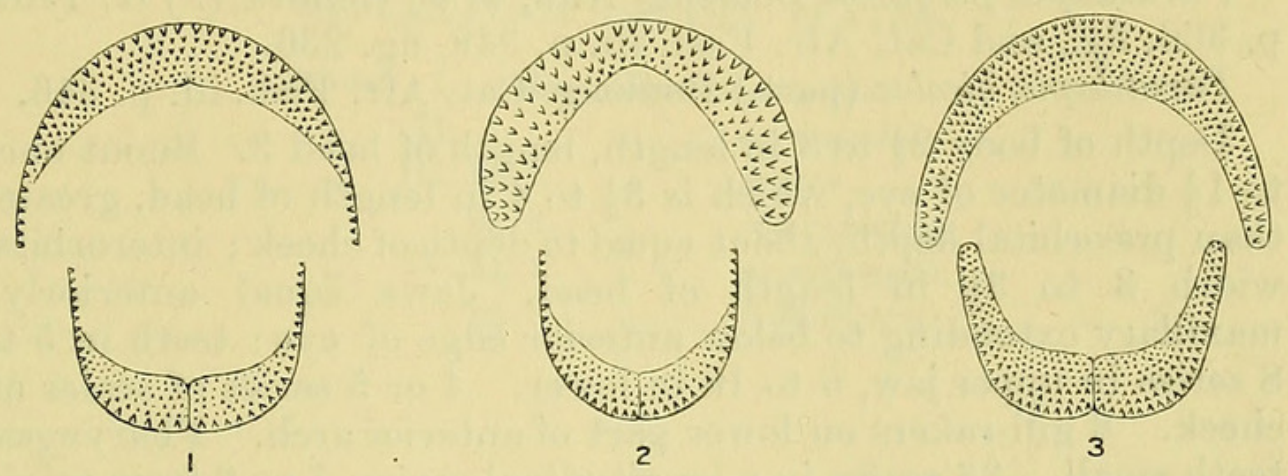

Dentition of 1. Haplochromis sauvagii; 2. Macropleurodus bicolor ;

3. Hoplotilapia retrodens.

Macropleurodus Bicolor Bouleng., 1906.

Paratilapia bicolor (part.) Bouleng. Cat. Afr. Fish. iii. p. 346, fig. 234.

Paratilapia retrodens (part.) Bouleng. t. c. p. 347.

Depth of body $2 \frac{2}{3}$ to $3 \frac{1}{4}$ in length, length of head 3 to $3 \frac{1}{3}$. Snout decurved, as long as or a little longer than diameter of eye, which is greater than præorbital depth and 4 in length of head; interorbital width 3 in head. Mouth wide; lower jaw a little shorter than upper; maxillary extending to below anterior edge of eye; 5 or 6 series of teeth in upper jaw, 4 or 5 in lower. 3 or 4 series of scales on cheek. Gill-rakers short and stout, 7 or 8 on lower part of anterior arch. Pharyngeal teeth small. 32 scales in a longitudinal series, 6 or 7 from origin of dorsal to lateral line. Dorsal XV 8-9; last spine $\frac{2}{5}$ length of head. Anal III 8-9. Pectoral as long as head, reaching anal. Caudal truncate. Caudal peduncle longer than deep. Olivaceous, with a faint dark lateral band or with irregular dark cross-bars extending on to vertical fins.

Lake Victoria.

Two specimens, 135 and $150 \mathrm{~mm}$. long, from Bunjako.

I take the figured specimen of $P$. bicolor as the type and so restrict the name to the species described above. 


\section{Hoplotilapia Hilgend., 1888.}

Cnestrostoma Regan, 1920.

Differs from Haplochromis in the dentition. 'Teeth small, conical, in rather broad bands, which are well-developed on the sides of the jaws, being formed of 3 or 4 series of teeth posteriorly.

L. Victoria.

\section{Hoplotilapia retrodens Hilgend., 1888.}

Paratilapia retrodens Hilgend. Sitzb. Ges. Nat. Fr. Berlin, 1888, p. 76.

Hemichromis retrodens Pfeff. Thier'w. O.-Afr. Fische, p. 19 (1896).

Paratilapia polyodon Bouleng. Ann. Mus. Genova, (3) iv. 1909, p. 306, fig., and Cat. Afr. Fish. iii. p. 349, fig. 236.

Paratilapia bicolor (part.) Bouleng. Cat. Afr. Fish. iii. p. 346.

Depth of body $2 \frac{1}{2}$ to 3 in length, length of head 3 . Snout once to $1 \frac{1}{3}$ diameter of eye, which is $3 \frac{1}{2}$ to 4 in length of head, greater than præorbital depth, about equal to depth of cheek ; interorbital width 3 to $3 \frac{1}{3}$ in length of head. Jaws equal anteriorly; maxillary extending to below anterior edge of eye; teeth in 5 to 8 series in upper jaw, 6 to 10 in lower. 4 or 5 series of scales on cheek. 8 gill-rakers on lower part of anterior arch. Pharyngeal teeth small. 33 scales in a longitudinal series, 7 or 8 from origin of dorsal to lateral line. Dorsal XV-XVI 9-11; last spine $\frac{1}{3}$ to $\frac{2}{5}$ length of head. Anal III 8-9. Pectoral as Jong as head, reaching anal. Caudal truncate. Caudal perluncle longer than deep. Traces of regular dark cross-bars and of a band along middle of side and another above lateral line, or irregular blackish cross-bars extending on to vertical fins.

Four specimens, 110 to $170 \mathrm{~mm}$. in total length.

\section{Platytaniodus Bouleng., 1906.}

Near Haplochromis, but jaws with very broad bands of small

Text-figure 14.

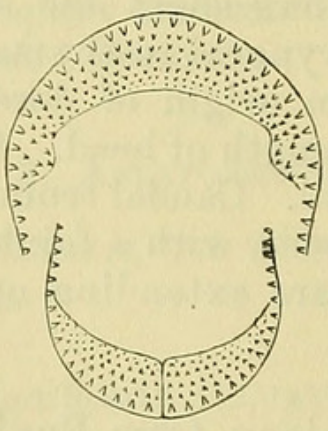

I

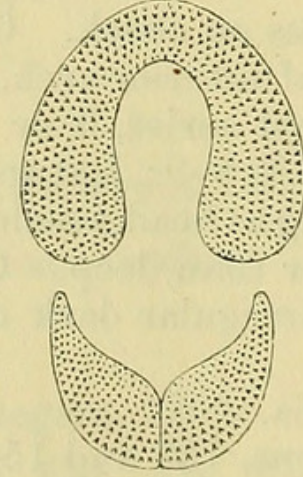

2

Dentition of 1. Haplochromis annectens; 2. Platytceniodus degeni. 
conical teeth, that of the upper jaw broader at the sides than in front.

L. Victoria.

Platyteniodus degeni Bouleng., 1906.

Platytceniodus degeni Bouleng. Cat. Afr. Fish. iii. p. 426, fig. 292.

Very near Haplochromis annectens, differing especially in the dentition.

Total length $140 \mathrm{~mm}$.

\section{EXPLANATION OF THE PLATES.}

Plate I. Haplochromis altigenis.

"II., serranoides.

, III. fig. 1. " dentex. fig. 2. " macrognathus.

" IV. fig. 1. " . gracilicauda. fig. 2. " longirostris. 


\section{$2 \mathrm{BHL}$ Biodiversity Heritage Library}

Regan, C. Tate. 1922. "9. The Cichlid Fishes of Like Victoria." Proceedings of the Zoological Society of London 1922, 157-191.

https://doi.org/10.1111/j.1096-3642.1922.tb03304.x.

View This Item Online: https://www.biodiversitylibrary.org/item/100598

DOI: https://doi.org/10.1111/j.1096-3642.1922.tb03304.x

Permalink: https://www.biodiversitylibrary.org/partpdf/72030

\section{Holding Institution}

Smithsonian Libraries

\section{Sponsored by}

Biodiversity Heritage Library

\section{Copyright \& Reuse}

Copyright Status: Public domain. The BHL considers that this work is no longer under copyright protection.

This document was created from content at the Biodiversity Heritage Library, the world's largest open access digital library for biodiversity literature and archives. Visit BHL at https://www.biodiversitylibrary.org. 